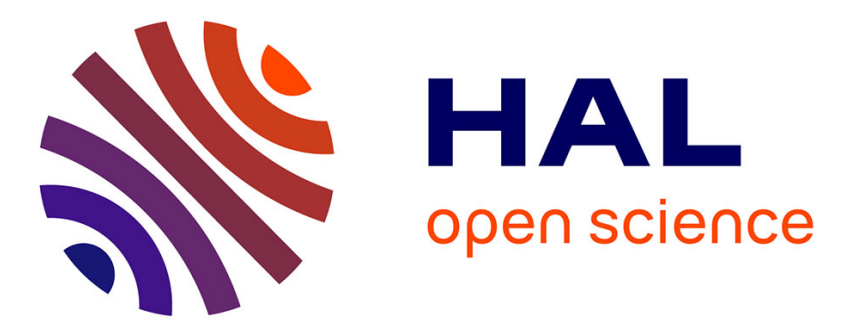

\title{
Late Miocene - Quaternary forearc uplift in southern Peru: new insights from 10 Be dates and rocky coastal sequences
}

Vincent Regard, Joseph Martinod, Marianne Saillard, Sébastien Carretier, Laëtitia Leanni, Laurence Audin, Kevin Pedoja

\section{To cite this version:}

Vincent Regard, Joseph Martinod, Marianne Saillard, Sébastien Carretier, Laëtitia Leanni, et al.. Late Miocene - Quaternary forearc uplift in southern Peru: new insights from 10 Be dates and rocky coastal sequences. Journal of South American Earth Sciences, 2021, 8th ISAG Special Issue, 109, pp.103261. 10.1016/j.jsames.2021.103261 . hal-03162682

\section{HAL Id: hal-03162682 \\ https://hal.science/hal-03162682}

Submitted on 8 Mar 2021

HAL is a multi-disciplinary open access archive for the deposit and dissemination of scientific research documents, whether they are published or not. The documents may come from teaching and research institutions in France or abroad, or from public or private research centers.
L'archive ouverte pluridisciplinaire HAL, est destinée au dépôt et à la diffusion de documents scientifiques de niveau recherche, publiés ou non, émanant des établissements d'enseignement et de recherche français ou étrangers, des laboratoires publics ou privés. 


\section{Late Miocene - Quaternary forearc uplift in southern Peru: new insights from ${ }^{10} \mathrm{Be}$ dates and rocky coastal sequences}

5 Vincent Regard ${ }^{1 *}$, Joseph Martinod ${ }^{2}$, Marianne Saillard ${ }^{3}$, Sébastien Carretier ${ }^{1}$, Laetitia Leanni ${ }^{4}$, Gérard Hérail ${ }^{1}$, Laurence Audin ${ }^{2}$, Kevin Pedoja ${ }^{5}$

1. Géosciences Environnement Toulouse/OMP, Université de Toulouse, CNES, CNRS, IRD, UPS, Toulouse, France

2. Univ. Grenoble Alpes, Univ. Savoie Mont Blanc, CNRS, IRD, IFSTTAR, ISTerre, Grenoble, France.

3. Université Côte d'Azur, IRD, CNRS, Observatoire de la Côte d'Azur, Géoazur, 250 rue Albert Einstein, Sophia Antipolis 06560 Valbonne, France.

4. Aix Marseille Univ, CNRS, IRD, INRAE, Coll France, CEREGE, Aix-en-Provence, France

5. Normandie Univ, Unicaen, Unirouen, CNRS, M2C 14000, Caen, France.

* corresponding author. E-mail: vincent.regard@get.omp.eu; phone: +33 561332645. Postal mail: GET, OMP, 14 avenue Edouard Belin, 31400 Toulouse, France

\section{Abstract}

We explore the coastal morphology along an uplifting $500 \mathrm{~km}$-long coastal segment of the Central Andes, between the cities of Chala (Peru) and Arica (Chile). We use accurate DEM and field surveys to extract sequences of uplifted shorelines along the study area. In addition, we consider continental pediment surfaces that limit both the geographical and vertical extent of the marine landforms. We establish a chronology based on published dates for marine landforms and pediment surfaces. We expand this corpus with new ${ }^{10} \mathrm{Be}$ data on uplifted shore platforms. The last $12 \mathrm{Ma}$ are marked by three periods of coastal stability or subsidence dated $\sim 12-11 \mathrm{Ma}, \sim 8-7 \mathrm{Ma}$ and $\sim 5-2.5 \mathrm{Ma}$ ago. The uplift that accumulated between these stability periods has been $\sim 1000 \mathrm{~m}$ since $11 \mathrm{Ma}$; its rate can reach $0.25 \mathrm{~mm} / \mathrm{a}$ (m/ka). For the last period of uplift only, during the last $800 \mathrm{ka}$, the forearc uplift has been accurately recorded by the carving of numerous coastal sequences. Within these sequences, we correlated the marine terraces with the sea level highstands (interglacial stages and sub-stages) up to MIS 19 (790 ka), i.e., with a resolution of $\sim 100 \mathrm{ka}$.

The uplift rate for this last period of uplift increases westward from $0.18 \mathrm{~mm} / \mathrm{a}$ at the Peru-Chile border to $\sim 0.25 \mathrm{~mm} / \mathrm{a}$ in the center of the study area. It further increases northwestward, up to $0.45 \mathrm{~mm} / \mathrm{a}$, due to the influence of the Nazca Ridge. In this study, we document an unusual forearc cyclic uplift with $\sim 4 \mathrm{Ma}-$ long cycles. This periodicity corresponds to the predictions made by Menant et al. (2020) based on numerical models, and could be related to episodic tectonic underplating (subducting slab stripping) beneath the coastal forearc area. 
Keywords: Neogene, Quaternary, Andes, coastal sequence, marine terrace, rasa, cosmogenic dating, episodic coastal uplift

\section{Introduction}

\subsection{Rationale}

The Neogene has recently been identified as the main period of relief acquisition in the Central Andes (Garzione et al., 2008). The Neogene uplift of the Andes has been studied and quantified principally in the Altiplano region. The area between the Altiplano and the coast (forearc) has also been uplifted, but probably to a lesser degree (e.g., Schildgen et al., 2007; Jordan et al., 2010; Evenstar et al., 2015). The coastal part of the Central Andes forearc currently seems to be uplifting almost everywhere, except in central Peru between 8 and $14^{\circ} \mathrm{S}$ (Regard et al., 2010; Melnick, 2016; Martinod et al., 2016b; Saillard et al., 2017), as indicated by uplifted marine terraces and rasas (e.g., Hsu et al., 1989; Goy et al., 1992; Machare and Ortlieb, 1992; Ortlieb et al., 1996; Saillard, 2008; Regard et al., 2010; Saillard et al., 2011, 2012; Regard et al., 2017) or uplifted Neogene formations (e.g., DeVries, 1998; Macharé et al., 1988; Pena et al., 2004; Vega and Marocco, 2004; Hall et al., 2008; Rodriguez et al., 2013; Alván and von Eynatten, 2014). The modern coastal uplift is affected by long wavelength progressive variations (Regard et al., 2010), or by more local short wavelength changes associated with tectonic deformations (for example in Ilo, Peru or in Mejillones in Chile; e.g., Audin et al., 2008; Victor et al., 2011; Saillard et al., 2012; Binnie et al., 2016). The uplift has also been variable over time at the million-year scale (Saillard et al., 2009; Regard et al., 2010; Martinod et al., 2016b).

In general, forearc regions are structurally and tectonically decoupled from the arc and back arc areas, and their evolution is different from that of active margin orogens. For example, whereas major shortening occurred in the main range during the Neogene, the forearc shows normal faults (Sébrier et al., 1985; Gonzalez et al., 2003; Victor et al., 2011; Saillard et al., 2011, 2012, 2017; Viveen and Schlunegger, 2018) or reverse faulting perpendicular to the convergence velocity (Allmendinger et al., 2005; Audin et al., 2008). The mechanisms that constrain the surface uplift also largely differ between the forearc region and the main Cordillera. While the uplift of the Cordillera mainly results from crustal thickening and the thinning/removal of the dense mantle lithosphere (Garzione et al., 2017; Martinod et al., 2020), basal accretion beneath the overriding lithosphere may largely control forearc vertical motions (Wells et al., 2003; Melnick et al., 2006; Menant et al., 2020).

The southern Peru coast exhibits numerous marine terrace sequences (Hsu et al., 1989; Goy et al., 1992; Ortlieb et al., 1996, 1996; Saillard et al., 2011). Researchers concentrated their efforts on areas where sediments are found, thereby allowing for electronic spin resonance (ESR), amino acid racemization or UTh dating to be carried out (Hsu et al., 1989; Ortlieb et al., 1992, 1996). More recently, terrestrial cosmogenic nuclides have proven their usefulness in dating marine abrasion landforms (Saillard, 2008; Saillard et al., 2011 in Peru; Quezada et al., 2007; Melnick et al., 2009; Saillard et al., 2009; Rodriguez et al., 2013; Jara-Muñoz and Melnick, 2015; Binnie et al., 2016; Martinod et al., 2016b in Chile). These works emphasize that it is hard to date precisely landforms older than $0.5 \mathrm{Ma}$. Other Neogene chronological milestones are given by: (i) the remnants of fan deltas (Pena et al., 2004; Alván and von Eynatten, 2014), (ii) the geomorphological evolution in relation to supergene mineralization (Quang et al., 2005), and (iii) the canyon incision history (Kober et al., 2006; Schildgen et al., 2007; Thouret et al., 2007; Wipf et al., 2008; Schildgen et al., 2009a). These milestones are indirect and are therefore not accurate indicators for uplift; 
consequently, the Plio-Pleistocene uplift history of the forearc is still uncertain, which limits our ability to link potential uplift variations with tectonic controls.

Herein, we take advantage of high accuracy DEM (TanDEM-X) to map uplifted shorelines, usually made of a fossil sea-cliff at its continental side and, at its sea side, a platform terrace either carved into the underlying rock formations or built with sediments. The terrace is sometimes not flat, due to erosion or because it was not well carved originally: we often prefer the term of uplifted (or fossil) shore. We compile both existing data and original ${ }^{10} \mathrm{Be}$ cosmogenic nuclide exposure ages to decipher the uplifted shore chronology up to $0.8 \mathrm{Ma}$ ago. In addition, we use fossil geomorphic features with the chronological information from published works to give insights into the earlier geomorphic evolution (up to $10 \mathrm{Ma}$ ago). These new observations indicate a specific behavior of the forearc, suggesting that it underwent $\sim 3 \mathrm{Ma}-$ long cycles of alternating rapid uplift vs. slower uplift or subsidence.

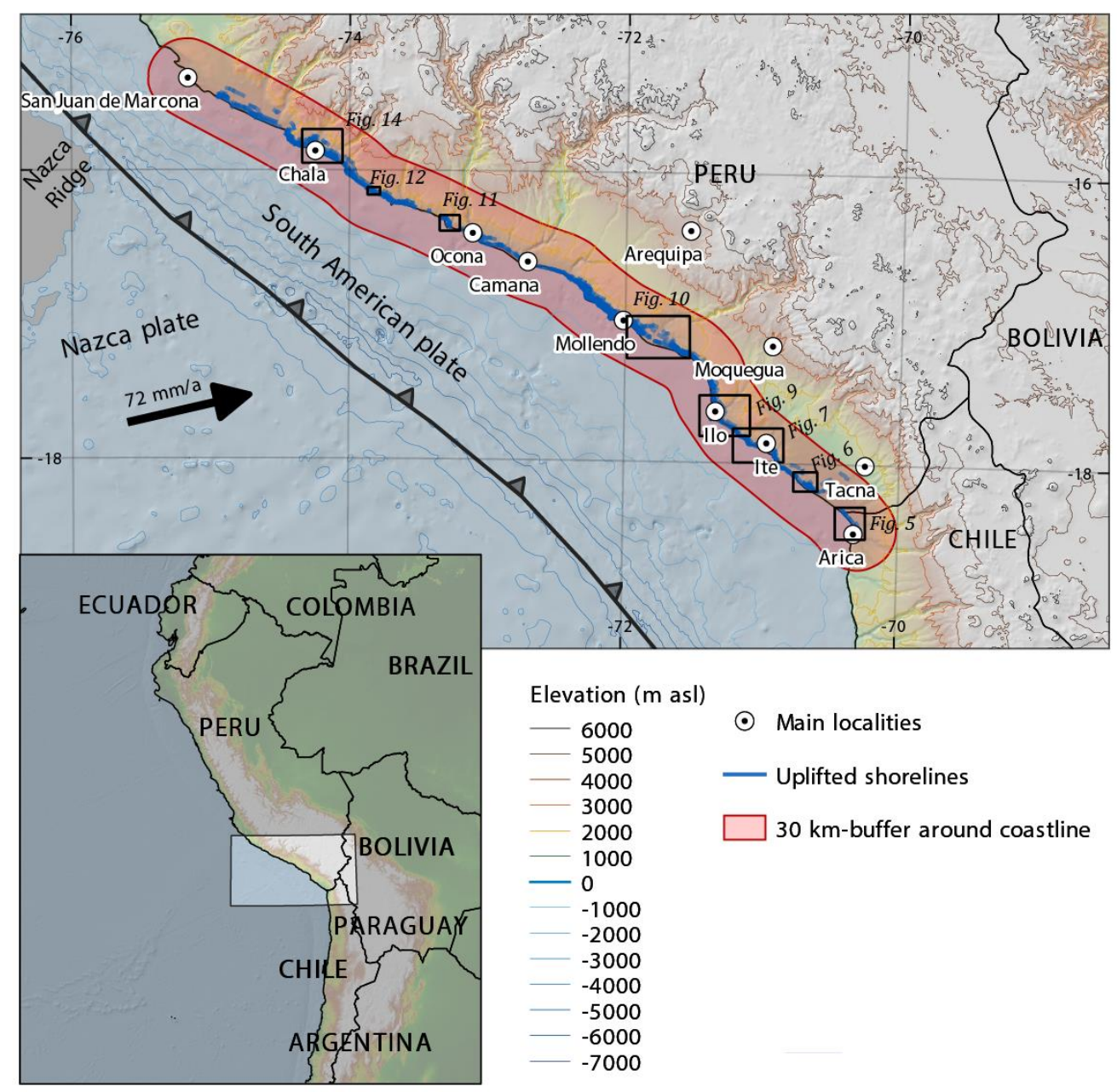

Figure 1. Study area location, showing the relief of the study area and the main localities cited in the text. The location of the following figures is highlighted. The buffer outlined in red color is the area analyzed in detail; the uplifted shorelines that have been mapped are shown in blue. The area is characterized by the subduction of the Nazca Plate under South America: it is figured by the trench and the convergence velocity (MORVEL, DeMets et al., 2010). (B\&W print) 


\subsection{Geology and geomorphology of the southern Peru and northern Chile}

coast

A classical cross-section of the Andes from the coast to the Altiplano displays various physiographic units in southern Peru and northern Chile. They are (i) the Coastal Cordillera, made up of basement rocks and culminating at 1000 to $2000 \mathrm{~m}$ in elevation, bordering the Pacific coast. The Coastal Cordillera disappears near the Peru-Chile border, a place that is sometimes called Arica Bend (Madella et al., 2016). (ii) To the northeast (or east in Chile), a longitudinal valley (parallel to the trench) separates the Coastal Cordillera from the inclined surface of the pampa, which slopes gently up to the Altiplano (elevation $\sim 4000 \mathrm{~m}$ ). Inbetween the pampa surface and the Western Cordillera, the longitudinal valley and the pampa surface have been filled by Cenozoic sediments (Roperch et al., 2006; Evenstar et al., 2017). (iii) The western Cordillera hosts the volcanic arc and marks the western boundary of the Altiplano (Figure 2). In southern Peru and northern Chile, the Coastal Cordillera and the longitudinal valley were close to the sea level in the early Miocene. In the longitudinal valley, the best evidence is a $25 \mathrm{Ma}$-old sediment layer left by a marine incursion (only found in southern Peru, Noble et al., 1985; Sebrier et al., 1988; Cruzado and Rojas, 2005; Schildgen et al., 2009a). Following this marine event, the uplift of the Coastal Cordillera made it a barrier for sediments, which were subsequently trapped in the longitudinal valley (Garcia et al., 2011; Evenstar et al., 2017). According to Evenstar et al. (2017), the area underwent major surfacing at approximately 23, 16, 11, 7 and $3 \mathrm{Ma}$ ago. The surfaces are nested, but the difference in elevation is small between the three oldest surfaces: together they constitute the main surface of the pampa (Quang et al., 2005). Of these, the $11 \mathrm{Ma}$-old surface is noteworthy. It generally corresponds to the end of the sedimentary infill made up of conglomerates sourced from the Western cordillera (Roperch et al., 2006; Evenstar et al., 2017). The main surface of the pampa was later incised, producing deep canyons where rivers flow. This entrenchment was interpreted as the consequence of the forearc uplift (Kober et al., 2006; Schildgen et al., 2007, 2009a; Garcia et al., 2011; Evenstar et al., 2017). Sediments from the Camana formation indicate that the rapid uplift initiated around 12-9 Ma (Alván and von Eynatten, 2014), compared to the 11-8 Ma period for the canyon incision initiation obtained using low temperature thermochronology by Schildgen et al. (2009a). The Neogene uplift has probably not been continuous, as suggested by the occurrence of a nested younger surface at $\sim 7 \mathrm{Ma}$ (Evenstar et al., 2017), Pliocene volcanic flows at the bottom of the current canyons (Garcia and Herail, 2005; Thouret et al., 2007) or marine terraces carved into Pliocene marine formations (e.g., in Camana, see below). Below, in the absence of other information, we consider that the top of the Coastal Cordillera has been shaped by $\sim 11 \mathrm{Ma}$, and that later nested surfaces only occur in limited areas at lower elevations. 

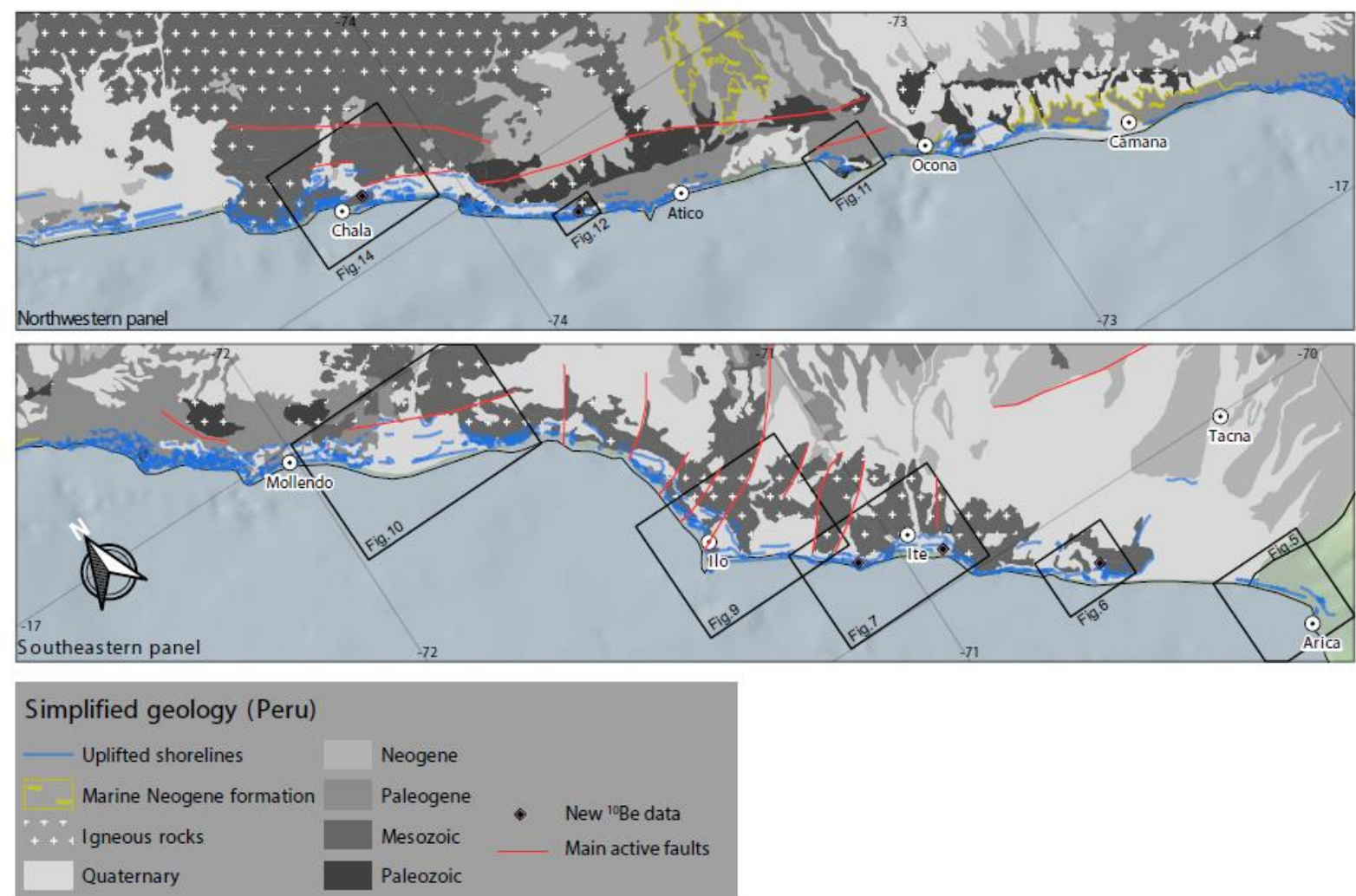

Figure 2. Geology of the study area (modified from INGEMMET, 1999). Main active faults are from INGEMMET (see also Costa et al., 2020). (B\&W print)

The recent evolution of the coast in southern Peru and northern Chile has been marked by Pliocene volcanic flows preserved $\sim 100 \mathrm{~m}$ above the bottom of the modern canyons. They are dated at $\sim 2.8 \mathrm{Ma}$ (Lluta canyon, Garcia et al., 2011) and 2.2 Ma (Ocoña canyon, Schildgen et al., 2007; Thouret et al., 2007; Schildgen et al., 2009a). This suggests that the rapid uplift was probably interrupted during the Pliocene, resulting in lava flows filling the canyons that had been previously deeply incised. Afterwards, there was some additional uplift, as recorded in sequences of emerged rocky strandlines and terraces (Regard et al., 2010; Melnick, 2016). At some locations, we observe that marine terraces emplaced over a sedimentary sequence of coastal sediments (probably Pliocene in age, see the geological maps from INGEMMET, 1999). Even if this observation should be further studied in order to understand the conditions for such a record, it indicates that the uplift has not been continuous and that a late Pliocene/early Quaternary period of subsidence or slow uplift occurred.

\section{Material and methods}

\subsection{Remote sensing determination of the fossil morphology}

We used TanDEM-X 12m-resolution DEM (provided by DLR-German Aerospace Center) to analyze the relief and to generate slope maps. The slope is visualized either in color or with greyscale colors, only for slopes higher than 10 degrees. Bing Aerial and Google Satellite WMS provided the background satellite imagery. 


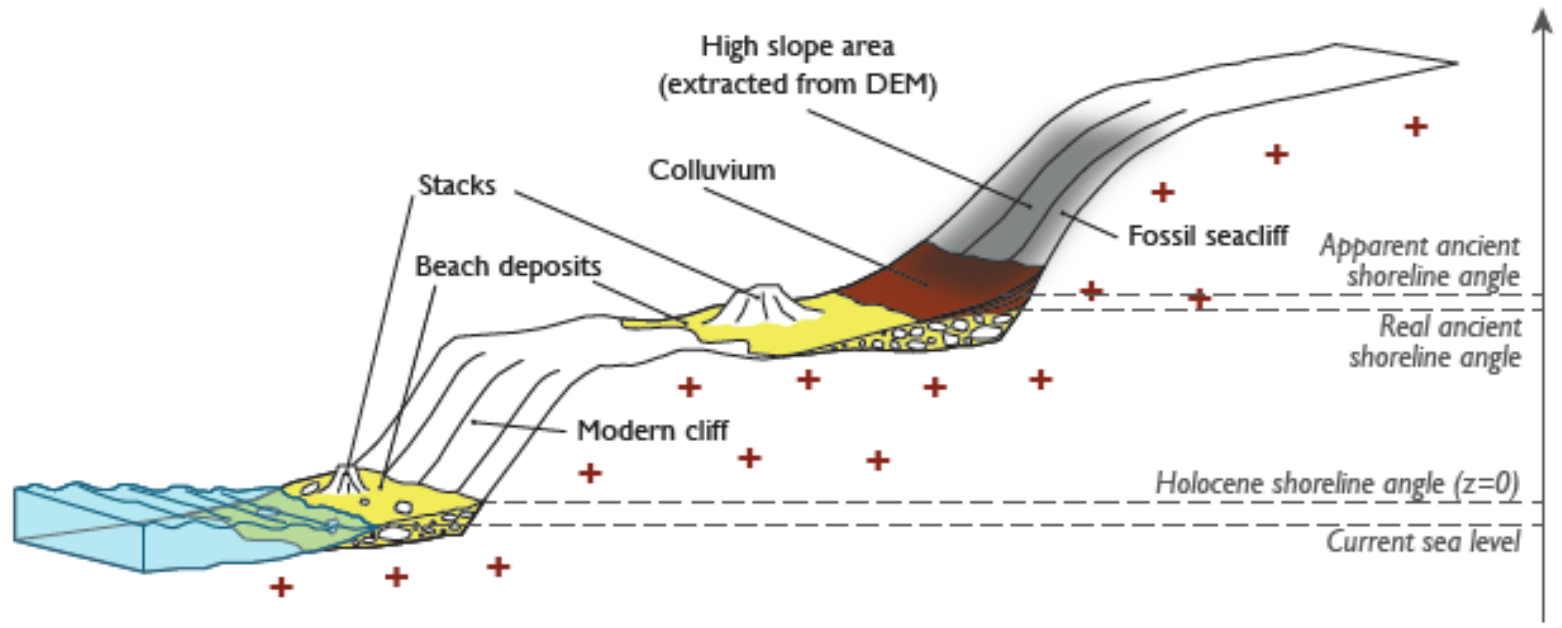

Figure 3. Schematic view of the uplifted shoreline. The active system is to the left. The altimetric reference $z=$ $\mathbf{O}$ is indicated. The right part shows a single raised fossil shoreline, now partly covered by colluvium mostly coming from the degradation of the cliff. The apparent ancient shoreline angle is thus a bit shifted from where it is in reality; it is located at the bottom of the high slope area in a DEM. (B\&W print)

We used this dataset to manually map the main cliffs and scarps along a 600-km-long coastal stretch alongshore southern Peru from $75^{\circ} \mathrm{W}\left(15.5^{\circ} \mathrm{S}\right.$, close to San Juan de Marcona) to the city of Arica close to the Chile-Peru border $\left(70.3^{\circ} \mathrm{W}, 18.5^{\circ} \mathrm{S}\right)$ (Figure 2$)$. The location of the fossil sea-cliffs is determined based on geomorphological features observed on satellite imagery and DEM slopes. Care is needed because former cliffs have been uplifted and partly eroded, marking a smoothed topographic step between marine terraces (Figure 3). Fossil sea cliffs are organized relatively parallel to the coast along high-slope strips (e.g., Regard et al., 2017). The location and elevation of the fossil cliff is recorded by their shoreline angle (or cliff toe), which is used to calculate the uplift rate (e.g., Perg et al., 2001; Pedoja et al., 2006; Saillard et al., 2009; Pedoja et al., 2011; Regard et al., 2017). The cliff toe is usually impeded by sediments deposited at the cliff foot (Figure 3), which adds uncertainty to the location of the fossil cliff (e.g., Pillans, 1983). These uncertainties lead to an elevation bias on the order of $\pm 2 \mathrm{~m}$. Although recent tools were developed to address this uncertainty (Jara-Muñoz et al., 2016), we think that a better resolution is beyond the scope of the present study. The remote sensing visualization allows a manual drawing of the cliff toe, cross-validated by field observations. These observations are geomorphological (cliff, stacks) as well as geological, providing evidence for paleo-shorelines with shells, beach rocks or beach pebbles (Figure 4). In the following, we differentiate some "main cliffs", corresponding to high fossil cliffs. They differ from simple cliffs, likely corresponding to a single glacial cycle (as observed in southern Peru, Saillard et al., 2011; and northern Chile, Martinod et al., 2016b), and are consequently limited in height ( $<<100 \mathrm{~m})$. 




Figure 4. Beach deposits backed by a fossil sea cliff $\left(73.1366^{\circ} \mathrm{W}, 16.43115^{\circ} \mathrm{S}, \sim 285 \mathrm{~m}\right.$ asl); with a SW (left) - NE (right) orientation. The pebbles to the left have a median size of $\sim 10 \mathrm{~cm}$; the total sediment thickness is $\sim 3 \mathrm{~m}$. The bedrock can be seen to the right, with cobbles at its toe (diameter up to $1 \mathrm{~m}$ ). The contact between the two deposits is close to vertical and constitutes a fossil sea cliff. (B\&W print)

TanDEM-X data are vertically referenced with respect to WGS84 ellipsoid, which has an average offset of $\sim 30 \mathrm{~m}$ with the geoid in the study area (Pavlis et al., 2012). Therefore, we subtracted the difference in elevation between the WGS84 ellipsoid and the EGM08 geoid (Pavlis et al., 2012) from the TanDEM-X elevation (between 24 and $32 \mathrm{~m}$ ). Consequently, in the following, the elevation will be given in meters above sea level ( $\mathrm{m}$ asl) and with this reference. The elevation is recorded at points along the paleoshorelines (seacliffs) at intervals of no more than $500 \mathrm{~m}$. The elevation uncertainty is probably $\sim 3 \mathrm{~m}$ for the DEM and its EGM08 reference. Taking into account the uncertainty in the drawing would probably increase the uncertainty up to $\sim 5 \mathrm{~m}$.

Our remote sensing analysis, based on the one hand on DEM elevation and slope analysis, and on the other hand on satellite images (see above), also revealed landforms related to faults and pediments. Faults are linear features that offset the landscape. Pediments (or "degradational surfaces" sensu Evenstar et al., 2017) are gently dipping continental surfaces associated with a well-developed drainage network, easily mapped by remote sensing (Evenstar et al., 2017). We only report them where they neighbor the coastal escarpment; we record their lowest elevation which indicates a maximum uplift for marine features.

\subsection{Cosmogenic dating}

Cosmogenic dating has been applied successfully to marine terraces (Trull et al., 1995; Perg et al., 2001; Kim and Sutherland, 2004; Quezada et al., 2007; Alvarez-Marron et al., 2008; Saillard et al., 2009, 2011; Kong et al., 2011; Rodriguez et al., 2013; Binnie et al., 2016; Martinod et al., 2016b; Binnie et al., 2020) and rock shore platforms (Choi et al., 2012; Regard et al., 2012; Hurst et al., 2016; Raimbault et al., 2018; Swirad et al., 2020).

Here, we present nine new ${ }^{10} \mathrm{Be}$ dates. We followed the same sampling strategy as in Martinod et al. (2016b), i.e. we sampled high shorelines and preferentially bedrock to avoid inheritance issues (clearly highlighted by Saillard et al., 2009). Out of the nine new dates provided here, eight come from bedrock samples (intrusive rocks); the last one, BR2, has been sampled in conglomerates (granulometry $<10 \mathrm{~cm}$ ), under a $30 \mathrm{~cm}$-thick sediment cover (Table 1 ).

Table $1 .{ }^{10} \mathrm{Be}$ samples and concentrations; density set to $2,700 \mathrm{~kg} \cdot \mathrm{m}^{-3}$. 


\begin{tabular}{|c|c|c|c|c|c|c|c|c|c|c|c|c|c|}
\hline Area & Sample name & Latitude & Longitude & Elevation & Sample & $\begin{array}{l}\text { Mass dissolved } \\
\text { quartz }\end{array}$ & Spike ${ }^{9} \mathrm{Be}$ & $+/-$ & Corrected ${ }^{10} \mathrm{Be} /{ }^{9} \mathrm{Be}$ & $+/-$ & depth & ${ }^{10} \mathrm{Be}$ & $+/-$ \\
\hline & & ( $\left.{ }^{\circ} \mathrm{S}\right)$ & $\left({ }^{\circ} \mathrm{W}\right)$ & (m asl) & & (g) & (10^15 at) & & $\left(\times 10^{-15}\right)$ & & (m) & (at/g) & \\
\hline Chala & $\mathrm{CH} 1$ & 15.8662 & 74.1909 & 170 & $\begin{array}{c}\text { Bedrock sea } \\
\text { stack }\end{array}$ & 9.9483 & 20444 & 61 & 863 & 27 & 0 & 1773693 & 55021 \\
\hline Atico & AT7B & 16.1468 & 73.8292 & 123 & $\begin{array}{c}\text { Bedrock sea } \\
\text { stack }\end{array}$ & 16.7848 & 20442 & 61 & 611 & 24 & 0 & 743994 & 28732 \\
\hline Atico & AT7C & 16.1489 & 73.8290 & 91 & Bedrock & 24.501 & 20440 & 61 & 529 & 16 & 0 & 441394 & 13815 \\
\hline Atico & AT7D & 16.1514 & 73.8310 & 37 & Bedrock & 24.7216 & 20440 & 61 & 506 & 16 & 0 & 418294 & 13663 \\
\hline Ite & IT2B & 17.9292 & 70.9175 & 48 & $\begin{array}{c}\text { Beach } \\
\text { pebbles }\end{array}$ & 25.8789 & 20408 & 61 & 1651 & 54 & 0 & 1302302 & 42552 \\
\hline Ite & IT6A & 17.8507 & 71.0967 & 113 & $\begin{array}{c}\text { Bedrock sea } \\
\text { stack }\end{array}$ & 0.5762 & 20276 & 61 & 40 & 4 & 0 & 1419146 & 146736 \\
\hline Ite & IT6B & 17.8504 & 71.0970 & 118 & $\begin{array}{c}\text { Bedrock sea } \\
\text { stack }\end{array}$ & 0.3849 & 20373 & 61 & 31 & 3 & 0 & 1621348 & 163129 \\
\hline Ite & IT6C & 17.8512 & 71.0965 & 112 & $\begin{array}{c}\text { Bedrock sea } \\
\text { stack }\end{array}$ & 0.308 & 20323 & 61 & 32 & 3 & 0 & 2105450 & 193909 \\
\hline $\begin{array}{l}\text { Boca del } \\
\text { Rio }\end{array}$ & BR2 & 18.1254 & 70.6427 & 78 & $\begin{array}{c}\text { Cimented } \\
\text { pebbles }\end{array}$ & 5.6292 & 20408 & 61 & 391 & 15 & 0.3 & 1416277 & 54054 \\
\hline
\end{tabular}

AMS Standard: NIST 4325, using an assigned value of of (2.79 \pm 0.03$) .10 E-11$ (Nishiizumi 2007).

The samples were processed using the standard procedures: after being crushed and sieved $(0.5-1 \mathrm{~mm})$ at the GET laboratory (Toulouse, France), the beryllium oxide was extracted at CEREGE and the ${ }^{10} \mathrm{Be}$ concentration was measured at AMS ASTER (CEREGE, Aix en Provence, France) (Braucher et al., 2015).

The exposure ages derived from the cosmogenic nuclides are very sensitive to erosion rates, especially for older ages (>300 ka). For this reason, even though the erosion rates seem to be very low in the Atacama, it is important to assess their maximum value. The gently sloping surfaces in the Atacama lead to very low erosion rates (e.g., Dunai et al., 2005; Hall et al., 2005; Carretier et al., 2018). The cosmogenic nuclides concentrations from the earth's surface indicate a maximum for the local erosion rate, even though the samples were collected first to calculate the surface ages. In northern Chile, based on a compilation of the published cosmogenic nuclide concentrations, Carretier et al. (2018) indicate that $>75 \%$ of the studied surfaces are eroding at rates smaller than $1 \mathrm{~m} / \mathrm{Ma}$. Marine terraces such as those studied here are generally almost flat, which reduces their erosion potential (see the discussion on marine terrace erosion rates in Martinod et al., 2016b). Another observation argues in favor of low erosion rates on these marine terraces in northern Chile and southern Peru. The cosmogenic nuclide content of the oldest terraces is incompatible with erosion rates $>1 \mathrm{~m} / \mathrm{Ma}$ : we calculated erosion rates of $<0.75 \mathrm{~m} / \mathrm{Ma},<1.08 \mathrm{~m} / \mathrm{Ma}$, and $<0.98 \mathrm{~m} / \mathrm{Ma}$ for, respectively, the three data from terrace $T 1$ of the Altos de Talinay (Saillard et al., 2009), the five samples from Caleta Chañaral (Martinod et al., 2016b) and the AT6C sample reported here. We conclude that the erosion rates occurring on the smooth landforms we sampled should be less than $1 \mathrm{~m} / \mathrm{Ma}$. Therefore, we base our analysis on erosion rates possibly varying between 0 and $1 \mathrm{~m} / \mathrm{Ma}$, which gives a realistic range for the exposure ages (Table 2). This assumption can be discussed on specific sites. For young landforms ( $<300 \mathrm{ka}$ ), these erosion rates do not modify significantly cosmogenic isotope concentrations, and therefore further quantifying their value is not necessary.

Table 2. Exposure ages estimated from the ${ }^{10} \mathrm{Be}$ concentrations. The $1 \sigma$ uncertainty is denoted by $+/-$. The elevation is in $\mathrm{m}$ above sea level, measured with a field barometer ( $5 \mathrm{~m}$ accuracy). The exposure ages are calculated for null $(e=0)$ and a surface erosion rate $e=1 \mathrm{~m} / \mathrm{Ma}$, at the current elevation, with Lal/Stone scaling in the Cronus web calculator (Lal, 1991; Stone, 2000; Phillips et al., 2016). The BR2 sample was collected at a depth of $30 \mathrm{~cm}$; it was covered by sand probably of aeolian origin: we corrected for this shielding, and therefore the age estimate is only a minimum. "-" indicates that the secular equilibrium is reached ("saturated" sample), i.e., the erosion rate must have been $<1 \mathrm{~m} / \mathrm{Ma}$ at these sites. 


\begin{tabular}{cccccccccc} 
Sample & $\begin{array}{c}\text { Latitude } \\
\text { ('S) }\end{array}$ & $\begin{array}{c}\text { Long. } \\
\text { ('W) }\end{array}$ & $\begin{array}{c}\text { Elev. } \\
\text { (m asl) }\end{array}$ & ${ }^{10}$ Be (at/g) & + +/- & $\begin{array}{c}\text { age } \boldsymbol{e}=\mathbf{0} \\
\text { (ka) }\end{array}$ & $\begin{array}{c}\text { +/- } \\
\text { age } \boldsymbol{e}=\mathbf{1} \\
\mathbf{m} / \mathbf{M a}(\mathbf{k a})\end{array}$ & + +/- \\
\hline CH1 & 15.87 & 74.19 & 170 & 1773693 & 55021 & 514 & 53 & 1271 & 621 \\
AT7B & 16.15 & 73.83 & 123 & 743994 & 28732 & 200 & 20 & 246 & 30 \\
AT7C & 16.15 & 73.83 & 91 & 441394 & 13815 & 120 & 11 & 133 & 14 \\
AT7D & 16.15 & 73.83 & 37 & 418294 & 13663 & 119 & 11 & 132 & 14 \\
IT2B & 17.93 & 70.92 & 48 & 1302302 & 42552 & 390 & 39 & 648 & 129 \\
IT6A & 17.85 & 71.1 & 113 & 1419146 & 146736 & 405 & 60 & 700 & 221 \\
IT6B & 17.85 & 71.1 & 118 & 1621348 & 163129 & 475 & 70 & 984 & 456 \\
IT6C & 17.85 & 71.1 & 112 & 2105450 & 193909 & 638 & 94 & - & - \\
BR2* & 18.13 & 70.64 & 78 & 1416277 & 54054 & $>400 *$ & & & \\
\hline
\end{tabular}

In the following, we use the published dates from Saillard (2008) and Saillard et al. (2011), based on the same calculation as for the new dates except where it corresponds to depth profiles. Table 4 reports these dating constraints with the addition of the dates obtained on the shells sampled in the marine terrace deposits (Ortlieb et al., 1992, 1996).

\subsection{Morphostratigraphic analysis (correlation with highstands)}

It has long been recognized that marine terraces, and more generally uplifted shore platforms, formed during sea level highstands (e.g., Zeuner, 1952; Chappell, 1974; Lajoie, 1986; Saillard et al., 2009; Pedoja et al., 2011; Regard et al., 2017; de Gelder et al., 2020). These highstands usually correspond to interglacial periods, i.e., odd MIS (marine isotopic stage). Although exceptionally, in a context of very high uplift rates, terraces correlative to glacial period highstands may be emerged and preserved (Caputo, 2007). We assume in the following that the fossil shores we sampled only formed during interglacial highstands in the low uplift rate context of the Central Andes (Melnick, 2016; Martinod et al., 2016b; Saillard et al., 2017).

In order to calculate the uplift rates $(U)$, we use the equation $U=(z-s \mid) / t$, where $z$ is the raised shore elevation, $s$ is the sea level at the time $t$ when it formed. As the raised shores are tied to the MIS ages, $t$ is actually the MIS age. The evaluation of $U$ is subject to uncertainties, the most important of which is probably the evaluation of the past sea level (see discussion in Siddall et al., 2006 and Caputo, 2007). Some authors advocate considering all of the highstands at the current sea level (Pedoja et al., 2011, 2014); this is interesting when comparing remote places because the local sea level can diverge from the global one (see Clark et al., 1978 for the Holocene example). If the past sea level is corrected, using its currently known level, this would only introduce small differences for old periods (MIS numbers $>11$ ), but these differences can be quite large for the youngest terraces, those from MIS $5 \mathrm{a}$ and $5 \mathrm{c}$, when the sea level was significantly different from the current one (Table 3). This is why we decided to make this correction for past sea levels. We use past sea levels from Siddal et al. (2006) and the Past Interglacials Working Group of PAGES (2016), with additional data for MIS (marine isotopic stage) 5a/5c (Cutler et al., 2003; Thompson and Goldstein, 2006). Information about the MIS age and sea level are compiled in Table 3.

Table 3. Synthesis of the main interglacial sea level highstands used in the present study (Cutler et al., 2003; Siddall et al., 2006; Thompson and Goldstein, 2006; Past Interglacials Working Group of PAGES, 2016; Spratt and Lisiecki, 2016 for MIS 17c).

$\begin{array}{lllll}\text { MIS } & \begin{array}{c}\text { MIS age } \\ (\mathrm{ka})\end{array} & +/- & \begin{array}{l}\text { Sea } \\ (\mathrm{m})\end{array} & \text { level } \\ & +/-\end{array}$




\begin{tabular}{rrrrr}
$5 a$ & 85 & 5 & -15 & 10 \\
$5 c$ & 100 & 7 & -15 & 3 \\
$5 e$ & 125 & 7 & 0 & 3 \\
$7 a$ & 190 & 7 & 0 & 3 \\
$7 \mathrm{e}$ & 225 & 7 & 0 & 3 \\
$9 \mathrm{a}$ & 280 & 6 & 2 & 5 \\
$9 \mathrm{c}$ & 321 & 6 & 8 & 10 \\
11 & 404 & 6 & 8 & 10 \\
13 & 500 & 10 & 0 & 10 \\
15 & 570 & 10 & 0 & 10 \\
$17 \mathrm{c}$ & 700 & 10 & -10 & available \\
19 & 790 & 10 & 0 & 10 \\
\hline
\end{tabular}

\subsection{Site by site analysis}

265 The sites are described from south to north: the distances refer to the city of Arica, the south-easternmost limit of the study area. The sites are illustrated by a detailed map and the elevation distribution for the shoreline angles. When available, the chronological data is discussed. There are two types of chronological data: absolute dates and morphostratigraphic correlations. The absolute dates come from U-Th and ${ }^{10} \mathrm{Be}$ data from the literature with the addition of our own ${ }^{10} \mathrm{Be}$ data (Table 4 and references therein). In addition,

270 when the terrace sequences are complete enough, we infer ages via morphological dating, using the paradigm that the sequence of the terraces reflects the sequence of the interglacials (e.g., Lajoie, 1986; Pedoja et al., 2014; Regard et al., 2017), although we cannot discard the fact that some past interglacial shores might be reoccupied, missing or totally eroded (e.g., Saillard et al., 2009). Nevertheless, this latter operation is all the more reliable as it is marked out by absolute dates: the best example is Chala where absolute dates are available and where the terrace sequence record is clear enough to extrapolate them.

\section{Morphotectonic DEM analysis}

\subsection{Study sites}

The sites are described from south to north: the distances refer to the city of Arica, the south-easternmost limit of the study area. The sites are illustrated by a detailed map and the elevation distribution for the shoreline angles. Table 4 presents a synthesis of the chronological constraints.

Table 4. Synthesis of the available ages for the uplifted shores in southern Peru. Elevation samples were recorded with a barometer corrected as often as possible to sea level. We estimate the accuracy of this elevation to be better than $\pm 5 \mathrm{~m}$. The raw correspondence with the marine isotopic stage (MIS) is given. It is sometimes adapted based on the consistency between the samples and the external geomorphic constraints; this results in the "MIS preferred" column and its corresponding "probable age" (see the text for further details). The lack of data for a few raised shorelines present in a globally well-documented sequence has been filled via a morphostratigraphic extrapolation ("Geomorphic sequence only"). The uplift rate is given in $\mathrm{mm} / \mathrm{a}$ (equivalent to $\mathrm{m} / \mathrm{ka}$ ). 


\begin{tabular}{|c|c|c|c|c|c|c|c|c|c|c|}
\hline Site & $\begin{array}{c}\text { Latitude } \\
\left({ }^{\circ} \mathrm{S}\right)\end{array}$ & $\begin{array}{c}\text { Longitude } \\
\left({ }^{\circ} \mathrm{W}\right)\end{array}$ & $\begin{array}{c}\text { Sample } \\
\text { elevation }(m)\end{array}$ & $\begin{array}{c}\text { Shoreline angle } \\
\text { elevation }(\mathrm{m})\end{array}$ & Data type & $\begin{array}{c}\text { MIS (raw } \\
\text { estimate) }\end{array}$ & $\begin{array}{c}\text { MIS } \\
\text { (preferred) }\end{array}$ & $\begin{array}{c}\text { Most probable } \\
\text { age (ka) }\end{array}$ & $\begin{array}{l}\text { Uplift rate } \\
\text { (mm/a) }\end{array}$ & Reference for dates \\
\hline Yauca & 15.60 & 74.69 & 133 & & 10Be Depth profile (3 points) & 9 & $9 c$ & 321 & 0.41 & Saillard, 2008 \\
\hline Tanaka & 15.74 & 74.46 & 90 & & 10Be Single exposure age & 7 & $7 e$ & 225 & 0.40 & Saillard, 2008 \\
\hline \multirow{9}{*}{ Chala } & & & & 33 & Morphostratigraphy & & $5 a$ & 85 & 0.39 & \\
\hline & 15.84 & 74.26 & 73 & 66 & $\begin{array}{l}\text { 10Be Depth profile (4 points). } \\
\text { Not accurate }\end{array}$ & $5 e ?$ & $5 e$ & 125 & 0.53 & Saillard, 2008 \\
\hline & 15.84 & 74.26 & 101 & 110 & 10Be Depth profile (4 points) & 9 (7 to 11$)$ & $7 e$ & 225 & 0.49 & Saillard, 2008 \\
\hline & 15.83 & 74.26 & 152 & 152 & 10Be Depth profile (4 points) & $\geq 7$ & $9 c$ & 321 & 0.47 & Saillard, 2008 \\
\hline & 15.87 & 74.19 & 170 & 189 & 10Be Single exposure age & $\geq 13$ & 11 & 404 & 0.47 & This work \\
\hline & & & & 232 & Morphostratigraphy & & 13 & 500 & 0.46 & This work \\
\hline & & & & 262 & Morphostratigraphy & & 15 & 570 & 0.46 & This work \\
\hline & & & & 302 & Morphostratigraphy & & 17 & 700 & 0.43 & This work \\
\hline & & & & 330 & Morphostratigraphy & & 19 & 790 & 0.42 & This work \\
\hline \multirow{4}{*}{$\begin{array}{l}\text { Aguada de } \\
\text { la Zorra }\end{array}$} & 16.15 & 73.83 & 37 & 57 & 10Be Single exposure age & $5 e$ & $5 e$ & 125 & 0.46 & This work \\
\hline & 16.15 & 73.83 & 91 & 97 & 10Be Single exposure age & $5 e$ & $7 e$ & 225 & 0.43 & This work \\
\hline & 16.15 & 73.83 & 123 & 130 & 10Be Single exposure age & 7 & $9 c$ & 321 & 0.40 & This work \\
\hline & & & & 158 & Morphostratigraphy & & 11 & 404 & 0.39 & This work \\
\hline 110 & 17.70 & 71.30 & & 20 & $\begin{array}{l}\mathrm{U} / \mathrm{Th} \text { and Amino acid } \\
\text { racemization }\end{array}$ & $5 e$ & $5 a$ & 85 & 0.24 & Ortlieb et al. 1992; Ortlieb et al. 1996 \\
\hline Ilo & 17.70 & 71.30 & & 25 & $\begin{array}{l}\mathrm{U} / \mathrm{Th} \text { and Amino acid } \\
\text { racemization }\end{array}$ & 7 & $5 e$ & 125 & 0.20 & Ortlieb et al. 1992; Ortlieb et al. 1996 \\
\hline Ilo & 17.70 & 71.30 & & 60 & $\begin{array}{l}\mathrm{U} / \mathrm{Th} \text { and } \mathrm{Amino} \text { acid } \\
\text { racemization }\end{array}$ & 9 & $9 a$ & 280 & 0.21 & Ortlieb et al. 1992; Ortlieb et al. 1996 \\
\hline 110 & 17.71 & 71.29 & & 80 & 10Be Depth profile (4 points) & $9 c$ & $9 c$ & 321 & 0.25 & Saillard, 2008 \\
\hline Ite & 17.93 & 70.92 & 48 & 100 & 10Be Single exposure age & 11 & 11 & 404 & 0.25 & This work \\
\hline Ite & 17.85 & 71.10 & 118 & 120 & $3 \times 10 \mathrm{Be}$ exposure ages & 11-to 15 & 13 & 500 & 0.24 & This work \\
\hline Boca del Rio & 18.13 & 70.64 & 78 & 81 & 10Be Single exposure age & $\geq 11$ & 11 & 404 & 0.20 & This work \\
\hline
\end{tabular}

290

Arica

Arica is located in northernmost Chile; we consider Arica to be the starting point (i.e., at "kilometer 0") for the calculation of all of the distances given below). North of the city, the coast is made up of a flat area, called Pampa de la Yarada coming down from Tacna, constituting the core of the Arica Bend, sensu Madella et al. (2016). Near the city of Arica, some remnants of coastal and alluvial terraces are found up to an 295 elevation of $150 \mathrm{~m}$ (Figure 5). Pampa de la Yarada displays clear evidence of pre-Holocene terraces. The sequence includes seven successive strandlines raised at the following elevations: $23,50,60,81,97,125$, and $157 \mathrm{~m}$ asl (Figure 5).

Only the Holocene shoreline has been dated using shell remnants collected to the north of Arica (Madella et al., 2017). With regard to other places in Chile (Regard et al., 2010; Martinod et al., 2016b) and in Peru (see below), it is tempting to relate the first terrace to MIS 5 and the terraces above it to successive previous odd MIS (interglacials). 

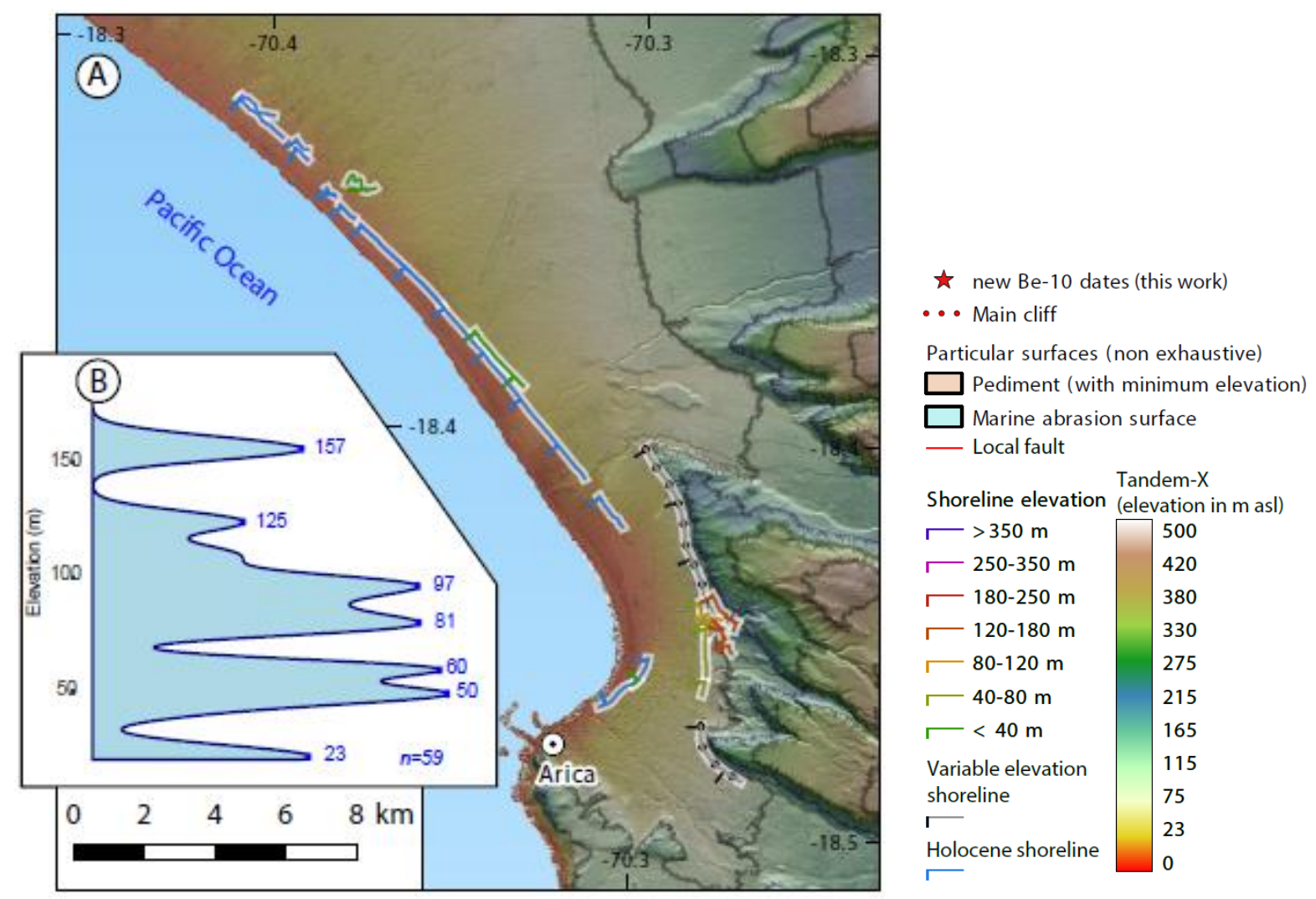

Figure 5. (A) Map of the uplifted shorelines in the Arica area (see the location in Figure 1). Note that to the north (Pampa de la Yarada), despite the very flat relief, raised shorelines can be detected, indicating an ongoing uplift. This legend applies to this figure as well as the following figures. This map shows the uplifted shorelines, the color of which indicates their shoreline angle elevation above the average level of the Holocene shoreline angle (see the Material and methods section); the elevation for the close-up views is given. The main cliffs are the largest ones, usually $>100 \mathrm{~m}$ high. Where detected (not in this map but in some of the following figures), some pediments and marine abrasion surfaces are mapped: this is not exhaustive, only the key ones for our interpretation are shown. Local active faults are drawn after INGEMMET (see also Costa et al., 2020). When available, the ${ }^{10} \mathrm{Be}$ dates are indicated (in the subsequent figures). The background image is a composite satellite image provided by Google ${ }^{\odot}$, improved by the shaded relief calculated from TanDEM-X, a mask for the ocean and an OpenStreetMap overlay. (B) Density plot of the mapped shoreline angle elevation with respect to the Holocene shoreline angle level; the main peak elevations are labeled. Shoreline angle elevation is

315 recorder at points at intervals of no more than $\mathbf{5 0 0 ~} \mathrm{m}$; the total number of elevation points is indicated ( $\mathrm{n}=\mathbf{5 9}$ in the present case). (B\&W print)

\section{Boca del Rio}

Located $50 \mathrm{~km}$ north of Arica $(x=50 \mathrm{~km}$ ), the area of Boca del Rio (mouth of the Sama River) displays a coastal plain. The fossil shoreline distribution in the area reveals a fossil embayment, a paleo-bay underlined by the strandlines with the shoreline angle raised at $\sim 45 \mathrm{~m}$ asl and $\sim 105 \mathrm{~m}$ asl (Figure 6 ). The main uplifted shorelines have shoreline angles lying at $37,49,75,85,102,116,134,173 \mathrm{~m}$; the level at $45 \mathrm{~m}$ is by far the most obvious one in the landscape. One single ${ }^{10} \mathrm{Be}$ concentration was obtained (BR2, > $400 \mathrm{ka}$ ), corresponding to the $81 \mathrm{~m}$ shoreline angle. In the absence of other data, we assign the $81 \mathrm{~m}$ shoreline to the interglacial period associated with MIS 11 (Table 4), correlating the $4^{\text {th }}$ shoreline level to the $4^{\text {th }}$ major interglacial before present. 


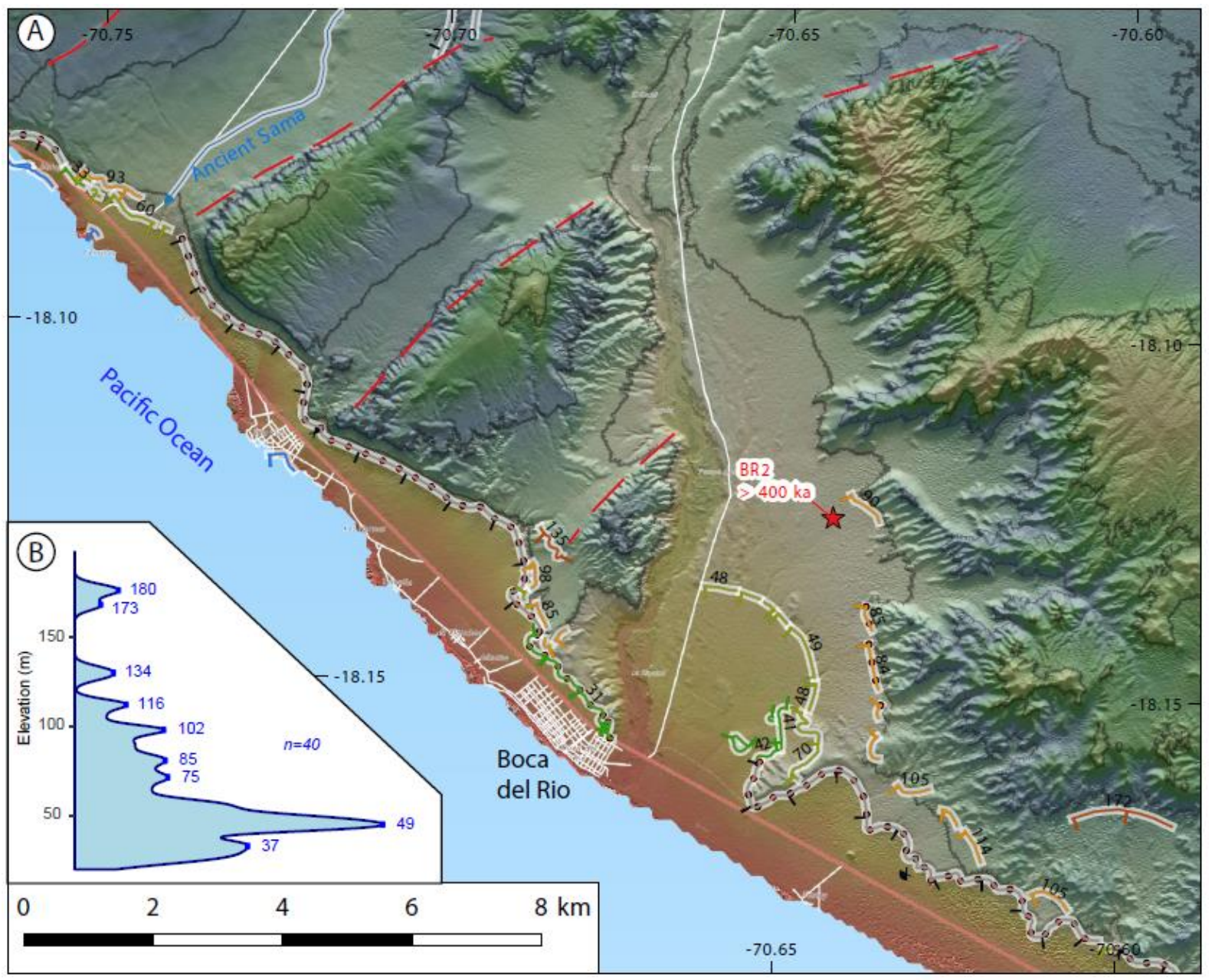

Figure 6. (A) Map of the uplifted shorelines in the Boca del Rio area, west of Tacna (see the location in Figure 1 and see Figure 5 for the legend). Note the strandline of a paleo-bay in the center of the image, for which the shoreline angle is $\sim 45 \mathrm{~m}$ above the Holocene angle. Higher paleo-bay strandlines are detected similar to the one at $102-116 \mathrm{~m}$, southeast of the preceding one. Apparent faults are found to the northwest (dashed red lines). (B) Density plot of the mapped shoreline angle elevation with respect to the Holocene shoreline angle level ( $n=40)$. (B\&W print)

Ite

The city of Ite is located $97 \mathrm{~km}$ away from Arica to the northwest, at the Locumba River mouth. The river produced several fluvial terraces, the continuity of which creates a spectacular shape of the parallel ancient shorelines at the coast (Figure 7). The main shoreline angles are found at 32, 54, 72, 123, 147, and $164 \mathrm{~m}$, highlighting an absence of remaining shoreline angles between 72 and $123 \mathrm{~m}$.

Following the procedure adopted and the correlation with the previous sites, the three lower terraces are likely contemporaneous with MIS 5, 7 and 9. IT2 was collected at a low elevation (48 $\mathrm{m}$ asl) but lies on an 340 ancient shore corresponding to a terrace correlated to a $\sim 100 \mathrm{~m}$ shoreline angle; its age of $>390 \mathrm{ka}$ is consistent with the expected chronology and could be assigned to MIS 11 (Table 4). Similarly, three samples to the northwest (site IT6, close to the Punta Picata archeological site), collected on a terrace with a shoreline angle elevation of $120 \mathrm{~m}$ asl, favor an age corresponding to MIS 11 to 15 . The geomorphic setting is suggestive of MIS 13: there is a $20-25$ m difference in elevation between the successive shoreline levels.

Remnants of degradational surfaces, probably pediments, covered by cobbles, are found at elevations as low as $\sim 310 \mathrm{~m}$, uphill from the IT6 site (Figure 8 ). They are nested largely below the main surface of the 
pampa; therefore, they may be related to the $7 \mathrm{Ma}$ or $3 \mathrm{Ma}$ period. Another, higher, pediment surface is also preserved at elevations between 500 and $700 \mathrm{~m}$ asl close to the coast in this area.

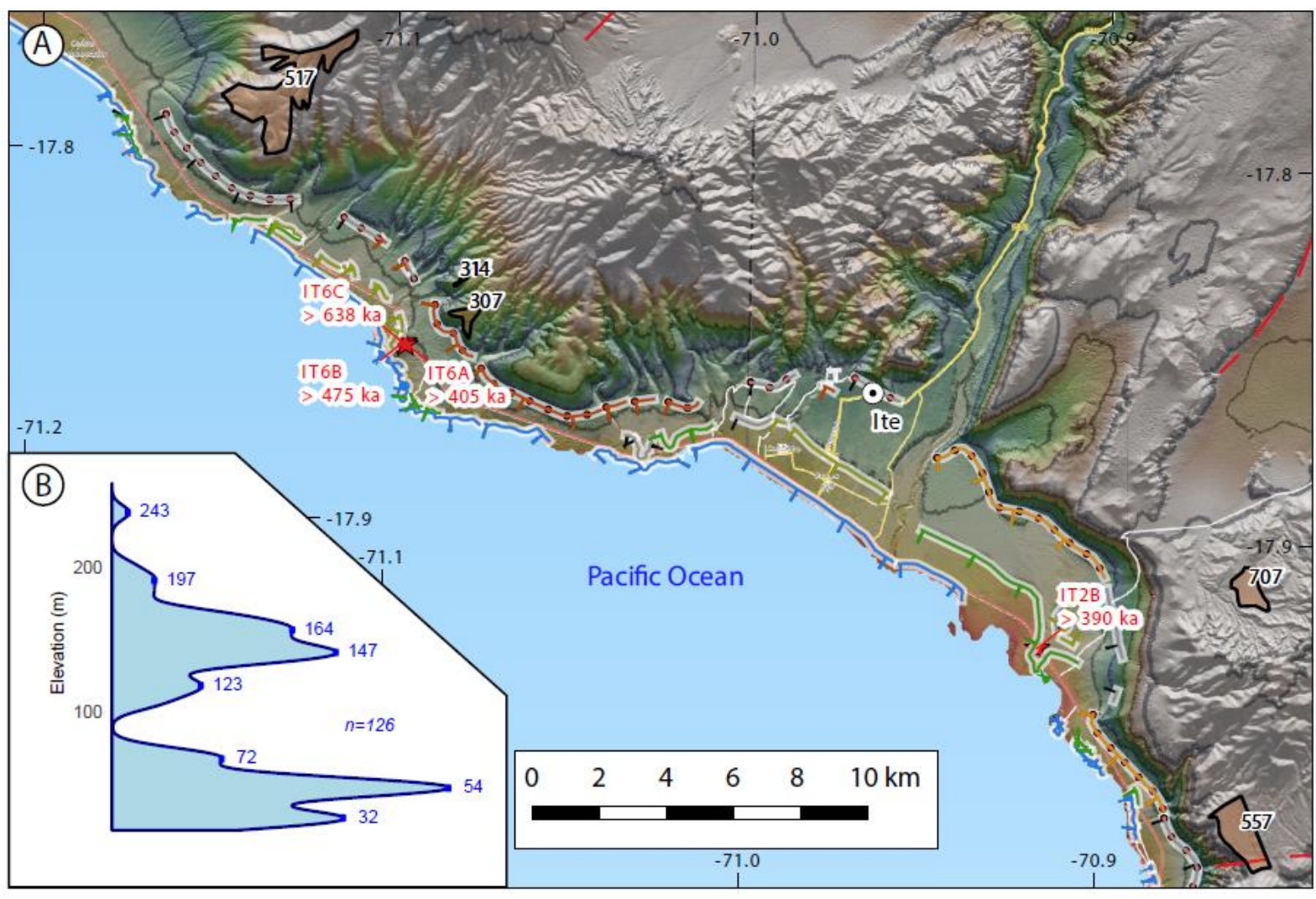

Figure 7. (A) Map of the uplifted shorelines in the Ite area (see the location in Figure 1 and Figure 5 for the legend). The center-east shows the mouth of a river: there, the terraces are made of fan material sourced from the river. More to the northwest, we dated $>400 \mathrm{ka}$ ancient shores with ${ }^{10} \mathrm{Be}$ at an elevation $\sim 115 \mathrm{~m}$. (B) Density plot of the mapped shoreline angle elevation with respect to the Holocene shoreline angle level ( $n=126)$. (B\&W print)

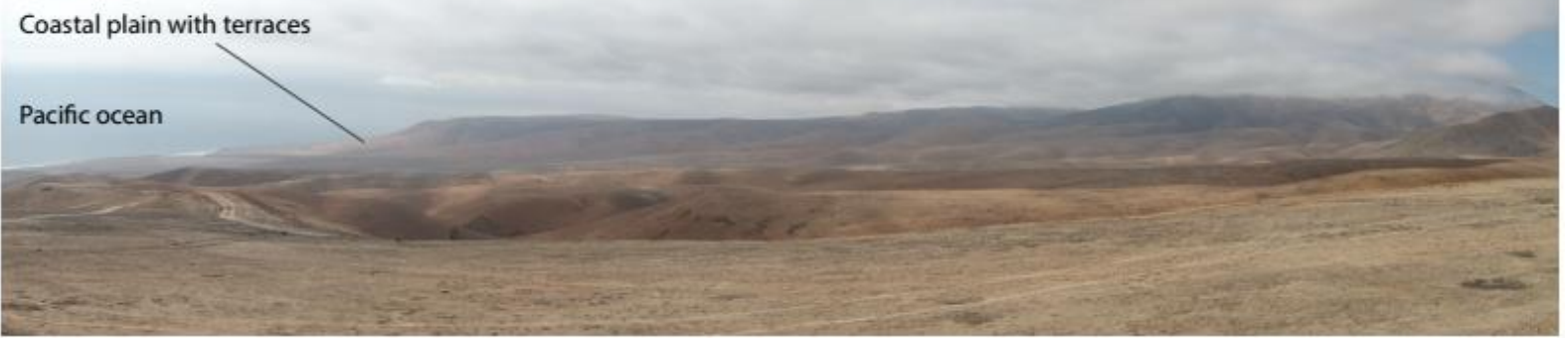

Figure 8. Example of a gently dipping pediment. It is separated from a coastal plain by an ancient cliff. The most elevated ancient shores in the coastal plain correspond here to the $>\mathbf{4 0 0}$ ka IT6 site. This site is located between Ite $(13 \mathrm{~km})$ and Ilo $(37 \mathrm{~km})$ at $\sim 310 \mathrm{~m}$ asl $\left(71.0827^{\circ} \mathrm{W}, 17.8512^{\circ} \mathrm{S}, 312 \mathrm{~m}\right.$, above site IT6 in Figure 7). (B\&W print)

Ilo

The city of llo is $\sim 140 \mathrm{~km}$ from Arica $(x=140 \mathrm{~km})$, between the Osmore River mouth to the north and the Punta Coles Peninsula to the south. Ilo is located over the Chololo active fault (Audin et al., 2008) (Figure 9); as a consequence, there are slight differences in the terrace elevations north and south of the city (Ortlieb et al., 1992). The morphology has been already studied (Ortlieb et al., 1996): it is marked by a 
narrow coastal plain, southeast from the Punta Coles Peninsula, exhibiting terraces (similar to the one visible in Figure 8). A high cliff (shoreline angle $\sim 82 \mathrm{~m}$ ) separates this coastal plain from a large surface lying between 150 and $250 \mathrm{~m}$ asl (Figure 9), clearly carved into the bedrock. This surface is found on both sides of the Chololo Fault (Figure 9). This surface is interpreted as marine. It is covered by debris fans in its upper part and overlooked by another marine planation surface at $\sim 450 \mathrm{~m}$ amsl (Ortlieb et al., 1996). The higher surface is deeply incised and has been related to the late Pliocene (Ortlieb et al., 1996), or more recently to a 7.9 Ma-old surface by Quang et al. (2005).

It is difficult to study the southern part of the llo area terrace record (Pampa de Palo) because it is extensively covered by aeolian deposits. For the present study, we use the morphostratigraphical sequence definition provided by Ortlieb et al. (1996). They recognized main terrace shoreline angles at 20, 25, 40, 80, and $120 \mathrm{~m}$ above sea level, which were only partly recorded with our methodology (Figure 9). These shoreline angles were attributed by Saillard (2008), after reconsidering the ages given by Ortlieb et al. (1996) with a new ${ }^{10} \mathrm{Be}$ datum, to MIS 5a, 5e, 7, 9c, and 11 . The previously described pediment surfaces are only $35 \mathrm{~km}$ southeast from llo (Figure 8 ).

The northern part of the llo area displays a series of marine terraces with associated shoreline angles. There, the record is not very accurate due to the degradation of the morphological features (Figure 9).



Figure 9. (A) Map of the uplifted shorelines in the Ilo area (see location in Figure 1 and see Figure 5 for the legend). The faults are drawn after Audin et al. (2008); the main, north-east trending one, is the Chololo Fault. The two density plots (pdf) show the shoreline angle elevations to the north $(B, n=87)$ and south $(C, n=112)$ of the Chololo Fault. (B\&W print) 


\section{Punta de Bombon and Mollendo}

The Punta de Bombon area is located at the mouth of the Tambo River, $220 \mathrm{~km}$ northwest from Arica. The area has been a major river mouth for at least $10 \mathrm{Ma}$ (Pena et al., 2004). The center of the area resembles the Ite area with an interaction between fluvial and marine risers. In any case, fossil cliffs are found up to $400 \mathrm{~m}$ above the current shores (Figure 10). The main shoreline angles are found at 23, 60, 77, 93 106, 135, 155, 220, $241 \mathrm{~m}$ above the Holocene shoreline angle.

In-between Ilo and Punta de Bombon, remnants of the Pampa surfaces are found over the main cliff at elevations as low as $860-920 \mathrm{~m}$ asl (Figure 9) while nested pediments and a surface (probably alluvial in origin) develop at an elevation of 450-500 m (Figure 10). Quang et al. (2005) connected them to the Cerro Sagollo stage ( 7.9 Ma).

In the southeastern corner of the map (Figure 10), clear terraces are carved into the pre-Cenozoic bedrock of the Guardiania Peninsula. Nearby, the Mio-Pliocene Chocolate formation lies over the Jurassic bedrock. On the Guardiania Peninsula, the discordance between the Chocolate Fm. and the Jurassic rocks is subhorizontal at $\sim 100 \mathrm{~m}$ asl (Bellido and Guevara, 1963) (Figure 10C). 

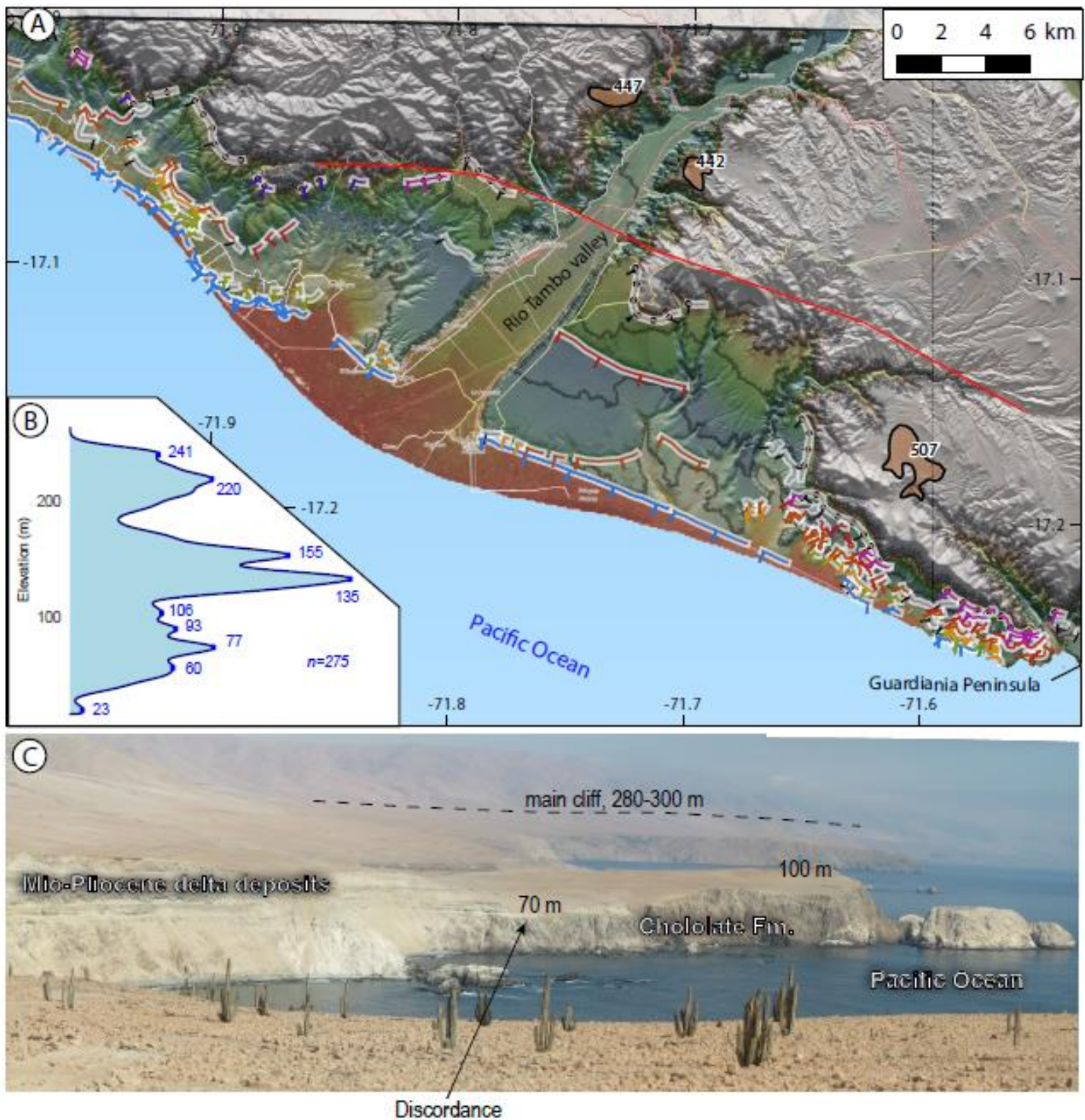

Figure 10. (A) Map of the uplifted shorelines in the Punta de Bombon area (see location in Figure 1 and see Figure 5 for the legend). (B) Density plot of the large Mollendo/Punta de Bombon area (100 km-long, $n=275)$. (C) Photo showing the coastal sequence on the Guardinia Peninsula in the southeastern corner of the map. The main cliff foot in the background lies at 280-300 $\mathrm{m}$ asl. (B\&W print)

To the northwest of Punta de Bombon, around Mollendo and up to the Vitor River mouth, the lower part of the coastal sequence includes numerous poorly defined marine terraces, with a discontinuous fossil seacliff separating them. It is rather difficult to get a clear idea of the general organization of the uplifted paleoshores. They are backed by a major cliff whose top reaches $\sim 400-500 \mathrm{~m}$, which is the same elevation as the pediment remnants along the Vitor Canyon (450-500 $\mathrm{m}$ asl). Other pediment surfaces are found north of Mollendo at $620 \mathrm{~m}$ asl. The Pampa surface is $>980 \mathrm{~m}$ asl above the lower reaches of the canyon of the Vitor River.

\section{Camana}

Like at Punta de Bombon, the area around the mouth of the Camana (or Majes) River, 335 km from Arica, displays extensive river delta sediments that are Mio-Pliocene in age (Camana formation; Alván and von 
Eynatten, 2014). The Late Cenozoic coastal record in the area is not obvious in the landscape, most probably because the sediments of the Camana formation have a low resistance to erosion, which prevents their preservation. The river is entrenched into a canyon whose summit surface is at $\sim 950 \mathrm{~m}$ asl close to the coast. Onshorewards, this summit surface is incised into the upper surfaces (Quang et al., 2005) and is probably correlative of the beginning of rapid incision. An intermediate pediment is found at $\sim 700 \mathrm{~m}$ asl.

\section{Ocoña and Pescadores}

At the Ocoña and Pescadores River mouths (respectively 382 and $400 \mathrm{~km}$ from Arica), the sequence is characterized by poorly preserved low-standing terraces. In contrast, high marine terraces, including abrasion surfaces and deposits (shells, coastal shingles) are well preserved and documented (Figure 11) at elevations up to $320 \mathrm{~m}$ asl (Figure 4). High shoreline angles are found at 167, 204, 245, 285, $331 \mathrm{~m}$. The largest cliff toe lies at $\sim 325 \mathrm{~m}$ asl. Pediment surfaces are found at elevations of 550-600 $\mathrm{m}$ asl.

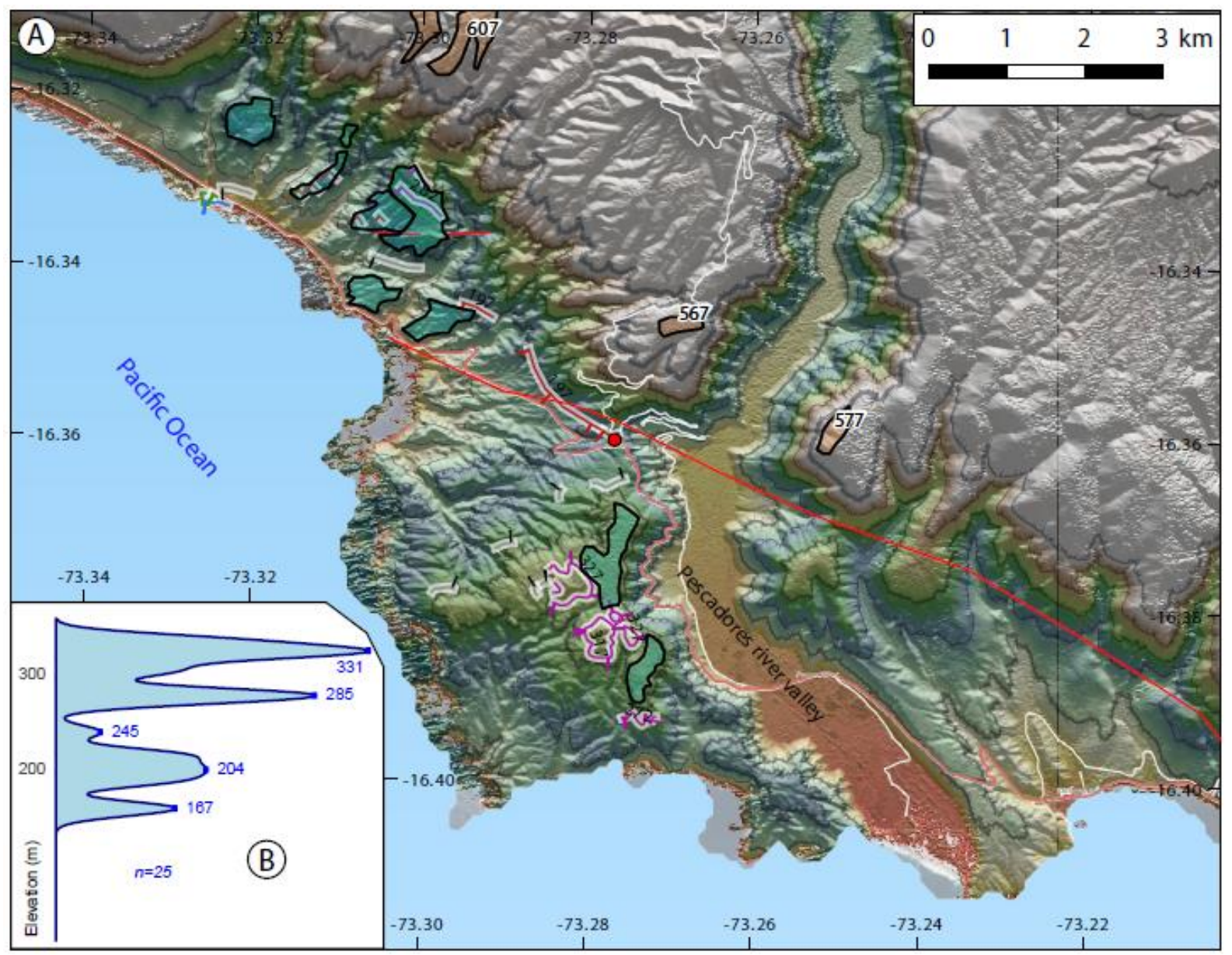

Figure 11. (A) Map of the uplifted shorelines in the Pescadores area (close to Ocoña River mouth, see the location in Figure 1 and see Figure 5 for the legend). The red dot indicates the occurrence of beach deposits with shells ( $280 \mathrm{~m}$ asl). In this area, the uplifted shorelines are not clearly marked although wide marine abrasion surfaces are preserved. (B) Density plot of the uplifted shoreline angle elevations $(n=25)$. (B\&W print)

\section{Atico and Aguada de la Zorra}

The coast between Pescadores and Atico ( 400 to $445 \mathrm{~km}$ from Arica) shows almost no terrace. The Pampa surface is $>1100 \mathrm{~m}$, and two sets of small patches of pediments are found at elevations of $540-610 \mathrm{~m}$ and $\sim 350 \mathrm{~m}$. Along this coastal stretch, we note many valleys that are filled by sediments. Their elevation close to the coast $(<5 \mathrm{~km})$ is $260-420 \mathrm{~m}$. 
The Aguada de la Zorra corresponds to a small area $467 \mathrm{~km}$ north of Arica, between Atico and Chala. This area is typical of a rasa morphology (Guilcher, 1974; Regard et al., 2010), i.e., the coastal morphology is made of a low slope surface, sometimes displaying small fossil cliffs, overlooked by a high cliff (> $800 \mathrm{~m}$ high here, with its base at 300 masl) or scarp limiting the Pampa (Figure 12). In the area of the Aguada de la Zorra, we sampled three terraces near their shoreline angle. The ${ }^{10}$ Be content shows three minimum ages at 119,120 and 200 ka (calculated with null erosion; the ages do not significantly differ if the erosion rate is $1 \mathrm{~m} / \mathrm{Ma}$; Table 2) for three sampled terraces at elevations of 37, 91 and $123 \mathrm{~m}$ asl, respectively. These ages yield a correlation of the lowest marine terrace to MIS $5 \mathrm{e}$ and 7 but the age distribution is puzzling as the two lower surfaces give the same age even though they differ in elevation by $50 \mathrm{~m}$. By analogy with the Chala area (see the next section), we prefer to correlate the lowermost terrace to MIS5e, the intermediary one to MIS7 and the uppermost one to MIS9. The discrepancy of the two uppermost data with this scenario implies a reworking of the uplifted shore. In this case, the removal of a loose cover may explain low ${ }^{10} \mathrm{Be}$ concentrations. This loose cover could correspond to aeolian deposits, which are frequently observed in this area.

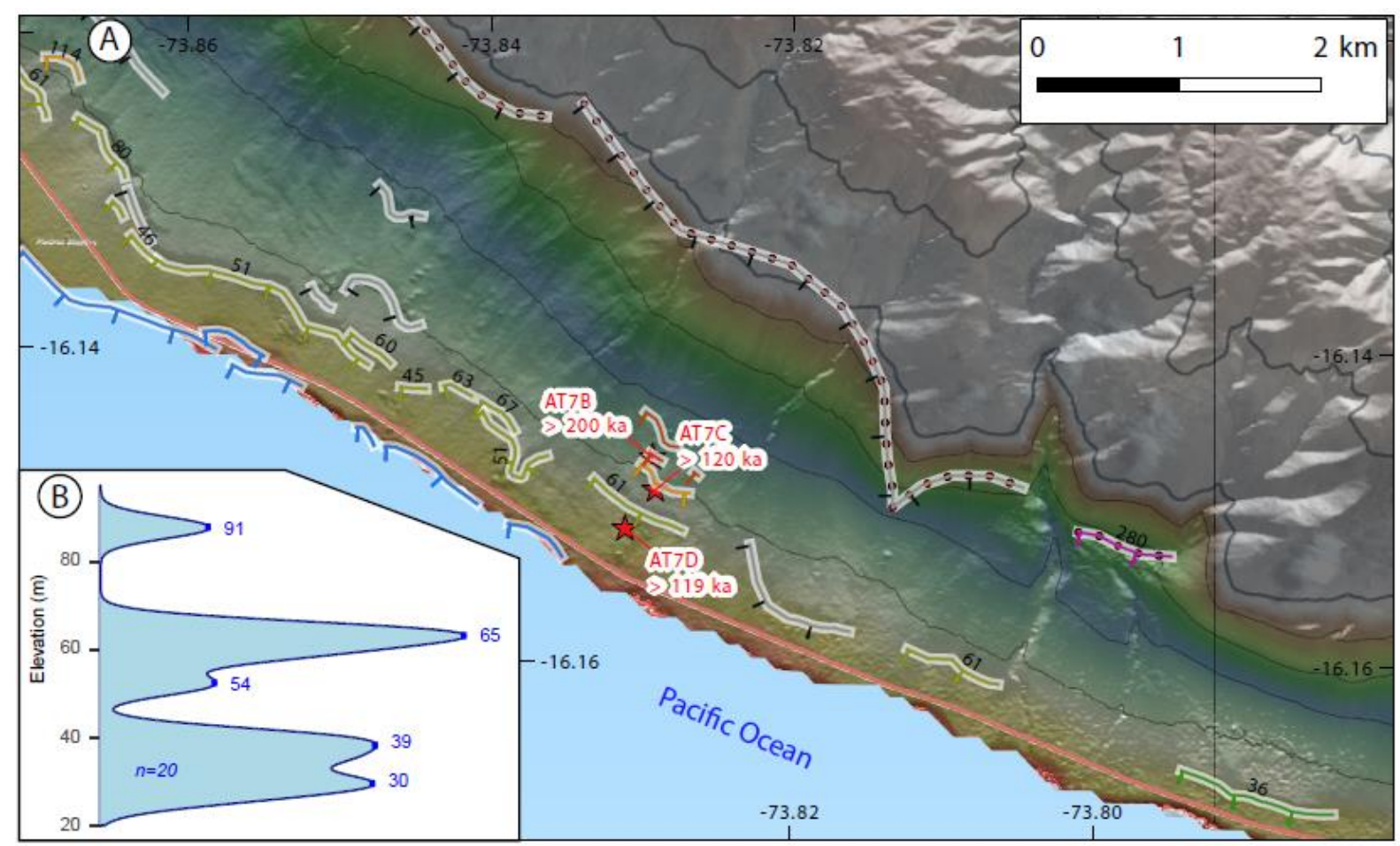

Figure 12. (A) Map of the uplifted shorelines west of Atico (Aguada de la Zorra, see the location in Figure 1 and see Figure $\mathbf{5}$ for the legend). The gentle slope between the shore and the main cliff is a rasa. Several intermediary shoreline angles (cliffs) are sometimes found preserved within the rasa surface. The ${ }^{10} \mathrm{Be}$ dates come from abrasion surfaces. The main fossil sea-cliff is $>800 \mathrm{~m}$ high (the toe is at $\sim 450 \mathrm{~m}$, top at $1300 \mathrm{~m}$ ). (B) Density plot of the uplifted shore elevation ( $n=20)$. (B\&W print)

Northward from the city of Atico, the rasa becomes wider as already discussed by Regard et al. (2010); its back cliff has a shoreline angle elevation that increases from $0 \mathrm{~m}$ (432 km away, Figure 13) to $290 \mathrm{~m}$ (540 $\mathrm{km}$ away). We observe that the main valleys (flowing to Chala and Atico), appear to have been filled up to the elevation at which the rasa is found. 


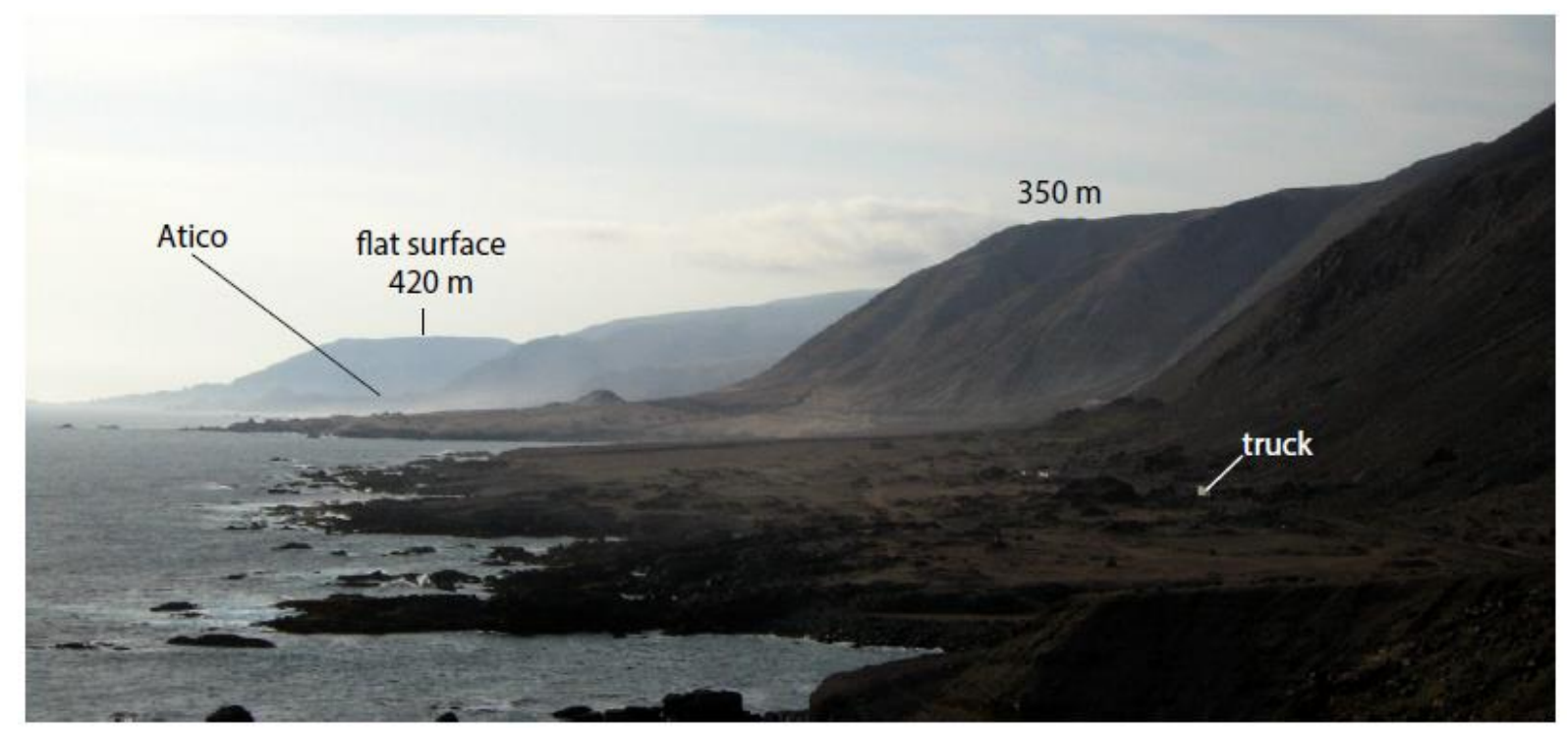

Figure 13. Interpreted photo looking towards the northwest of the coastal sequence $10 \mathrm{~km}$ south of Atico, at $\mathrm{km} 432.5\left(73.62^{\circ} \mathrm{W}, 16.25^{\circ} \mathrm{S}\right)$. The white square to the right is a truck and its trailer. The background corresponds to the approximate location of the city of Atico. The rasa is backed by a major cliff whose top in the foreground lies at $\sim 350 \mathrm{~m}$ asl, at a similar elevation as a pediment detected uphill from the truck. In the background, to the left, the flat summit surface lies at $\sim 420 \mathrm{~m}$ asl; it has the characteristics of a pediment. The rasa width and elevation increase towards the northwest (background). (B\&W print)

\section{Chala}

The town of Chala is situated $520 \mathrm{~km}$ northwest from Arica. The Chala sequence is emblematic as it is extremely well preserved and includes tens of successive shorelines (Goy et al., 1992; Saillard, 2008). The Chala sequence has been defined in the bay, north from the city (Figure 14). The area east of the city displays a wide uplifted shore platform; several intermediary shoreline angles (cliffs) are sometimes found preserved within this surface, e.g., at sampling site CH1 (Figure 14). The Chala Valley, whose mouth is in Chala Bay is wide in its lower reach, probably filled by sediments, up to the elevation at which the rasa is found ( 345 m, Figure 14).

Chala Bay represents a good reference for the terrace sequence. We observed main shoreline angles at 33, 68, 96, 110, 152 and $206 \mathrm{~m}$ which were correlated to the highstands associated to MIS 5a, 5e, 7a, 7e, 9c, and 11, respectively (Goy et al., 1992; Saillard, 2008). Our ${ }^{10}$ Be analysis for $\mathrm{CH} 1$ yielded an age of $>514 \pm 53$ $\mathrm{ka}$ on the uplifted rocky shore to the southeast of Chala, associated with a shoreline angle at $190 \mathrm{~m}$ asl. This latter was previously correlated to MIS 11 ( 405 ka BP Goy et al., 1992; Saillard, 2008); our new age would best correlate to the MIS 13 highstand, implying a lower uplift rate than previously proposed. In terms of the morphostratigraphy for the lowermost levels, an age of MIS 11 would best suit the $\mathrm{CH} 1$ position.

Our preferred scenario is to follow the scenario proposed by Saillard (2008) in which it is possible, although not likely, that the $\mathrm{CH} 1$ rocky shore dates back to the MIS 11 interglacial, considering the uncertainty on the $\mathrm{CH} 1$ concentration. The uplift rate should be around 0.42 to $0.49 \mathrm{~mm} / \mathrm{a}$ (Table 4). The main cliff feet are at an elevation of 270-420 m; the top of these cliffs is usually at elevations $>1000 \mathrm{~m}$. If the uplift rate remained stable, the main cliff age ranges between 560 and 1000 ka. 


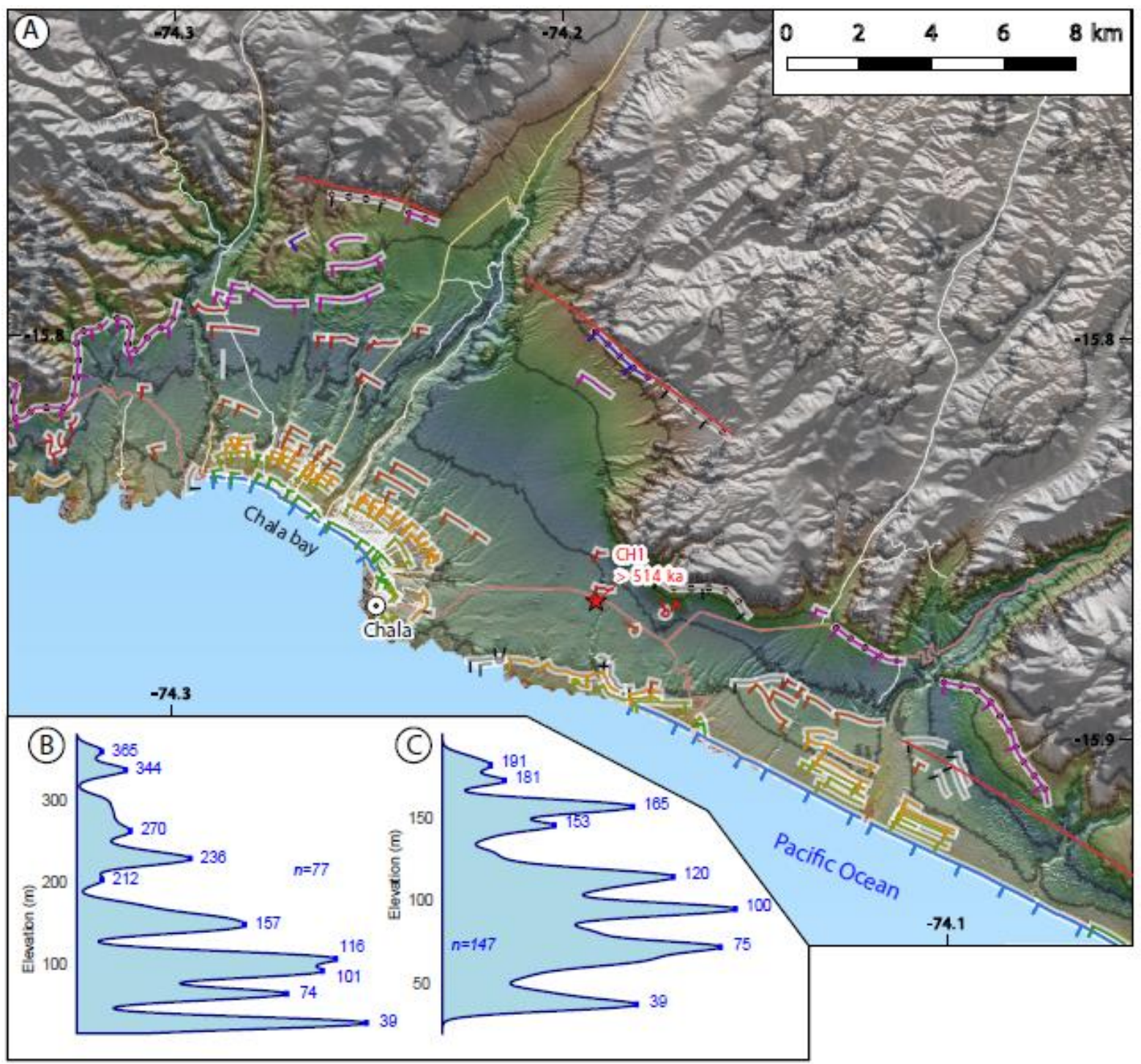

Figure 14. Map of the uplifted shorelines in the Chala area (see the location in Figure $\mathbf{1}$ and see Figure $\mathbf{5}$ for the legend). Note that the valleys are wide and seem to connect to the main cliff level. The two density plots are representative of either the whole area $(C, n=147)$ or only the area of the marine terraces in Chala Bay (B, $\mathrm{n}=77$ ), northwest from Chala. (B\&W print)

\subsection{Compilation of the uplift information in southern Peru}

Uplifted shorelines are widespread throughout the study area, as emphasized by Figure 2 and Figure 15.

These uplifted shorelines are usually observed at elevations up to 200-250 m, and sometimes they reach an elevation of 400-500 m (Figure 15). At least eight levels of uplifted shorelines are preserved in the morphology throughout the study area (Figure 15 and Figure 16). In some places, the terraces are less visible, such as around Camana, where they were likely removed by the erosion of their soft substratum, which is prone to erosion. 

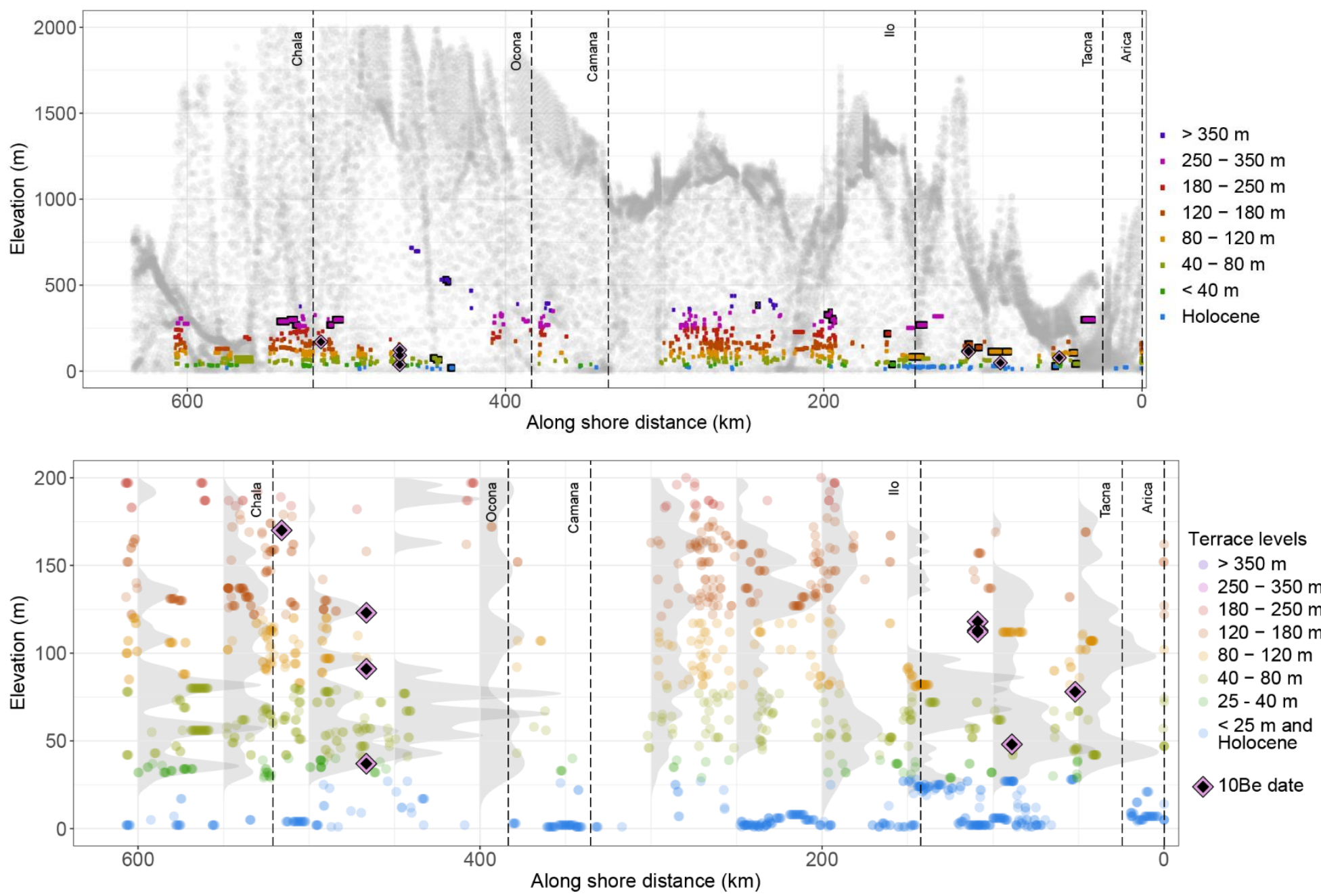

Figure 15. Distribution of the uplifted shorelines along the study area. The light gray points in the background represent the elevations within a $\mathbf{3 0} \mathbf{~ k m}$-wide area parallel to the coast (buffer, Figure 1). The colored points in the foreground represent the uplifted shoreline elevation; the thick points indicate major cliffs (see the maps). Bottom: zoom on the elevations lower than $200 \mathrm{~m}$ with the addition of the cosmogenic sampling. Background: density plots for the $50 \mathrm{~km}$ bins. The $\mathbf{3 5 0 - 3 0 0 ~ k m}$ bin is not drawn because there are not enough terraces and therefore this bin is unrepresentative. (B\&W print)

In order to understand the spatial distribution of the terrace ages, we assigned each marine terrace level 510 to an interglacial (MIS, Table 5). To do so, we first established clean sequences, where the ages provide absolute temporal constraints and fix the sequence, in the key study sites (Chala, Aguada de la Zorra, Pampa de Palo south of Ilo, and Ite). We sometimes used other published data to refine the morphostratigraphy of the sequence. For example, in Pampa de Palo, south of Ilo, our preferred morphostratigraphy is MIS 5a, 5e, 9a and 9c for the marine terrace levels at elevations of 20, 25, 60 and $80 \mathrm{~m}$. It differs from Saillard's 515 interpretation (2008, MIS 5e, 7, 9 and 9c) but is still found within the uncertainty of the published dates and ensures a relatively constant uplift rate for the last $330 \mathrm{ka}$ (0.20-0.25 mm/a, see Table 4). A second step was to identify the key sequences (like in Arica or Punta de Bombon/Mollendo) where the morphological dating was quite obvious (one terrace for each interglacial). Finally, we drew density plots in the $50 \mathrm{~km}$ bins, recorded the shoreline angle sequences and propagated our correlations in this record (Table 5). The plot of the data in Table 5 (Figure 16$)$ shows that the uplift slightly increases ( $50 \%)$ from Arica $(0.20 \mathrm{~mm} / \mathrm{a})$ to Pescadores $(0.30 \mathrm{~mm} / \mathrm{a}), 400 \mathrm{~km}$ to the northwest. Between Pescadores and Chala, it quickly increases in $125 \mathrm{~km}$ ( 60\%, i.e., MIS 19 lies at $245 \mathrm{~m}$ asl in Pescadores and at $344 \mathrm{~m}$ asl in Chala bay). The uplift rate is of $0.49 \mathrm{~mm} / \mathrm{a}$ on average at Chala (sites Chala and $525 \pm 25 \mathrm{~km}$ ). 
The correlations of the main shoreline angles with MIS (Table 5 and Figure 16) are based on their elevation, which is known with an accuracy of about $\pm 5 \mathrm{~m}$. This accuracy leads to scattering around the trend curves (Figure 16). Combined with the lack of conservation of certain shoreline angles, this could lead to a misallocation of a shoreline angle to a close MIS. However, the curves presented in Figure 16 are relatively parallel and consistent with the data, giving confidence in our correlation of the main shoreline angles with MIS. Given the accuracy of $\pm 5 \mathrm{~m}$ on shoreline angle elevation, the uncertainty on MIS ages (Table 3), and a possible misallocation to a close MIS older than MIS11, we estimate the accuracy of uplift rates to be $<20 \%$ (Table S1).

Table 5. The main shoreline angles and their correlations to MIS along the study area. Dated shoreline are shown in bold. The uplift rates are the average of the uplift rates calculated for every marine terrace (for the individual estimates, see Table S 1). The lowermost pediment age is obtained considering the uplift rate calculated above, and assuming it has been constant since the formation of the pediment.

\begin{tabular}{|c|c|c|c|c|c|c|c|c|c|c|c|c|c|c|c|c|c|c|c|}
\hline Site & & Chala & & $\begin{array}{l}\text { Aguada de } \\
\text { la Zorra }\end{array}$ & & Pescadores & & & & $\begin{array}{l}\text { P. de } \\
\text { Bombon/ } \\
\text { Mollendo }\end{array}$ & & & $\begin{array}{l}\text { Ilo: Pampa } \\
\text { de Palo }\end{array}$ & & Ite & & $\begin{array}{l}\text { Boca } \\
\text { del } \\
\text { Rio }\end{array}$ & & Arica \\
\hline$x(\mathrm{~km})$ & 525 & 524 & 475 & 467.5 & 425 & 402 & 375 & 325 & 275 & 240 & 225 & 175 & 130 & 125 & 100 & 75 & 50 & 25 & 0 \\
\hline$+/-$ & 25 & 3 & 25 & 2 & 25 & 7 & 25 & 25 & 25 & 50 & 25 & 25 & 10 & 25 & 15 & 25 & 5 & 25 & 20 \\
\hline MIS 5a & 39 & 33 & & & & & & & & & & & 20 & & & & & & \\
\hline MIS 5c & & & 48 & & 47 & & & & & & & & & & & & & & \\
\hline MIS 5e & 72 & 68 & 61 & 57 & 58 & & 38 & & 33 & 23 & & & 25 & & & & & & 21 \\
\hline MIS 7a & 101 & 96 & 82 & & & & & 43 & 45 & & & & & 31 & 32 & 35 & & & \\
\hline MIS 7e & 121 & 110 & 101 & 97 & 95 & & 68 & 56 & 56 & 60 & 53 & 41 & & 49 & 54 & 49 & 49 & 46 & 49 \\
\hline MIS 9a & 143 & & & & & & & & 69 & & 62 & 58 & 60 & & & & & & \\
\hline MIS 9c & 164 & 152 & 129 & 130 & & & & & 87 & 77 & 78 & & 80 & 82 & 72 & 74 & 75 & & 59 \\
\hline MIS 11 & 192 & 206 & 171 & 158 & & & 115 & & 115 & 106 & 106 & & & 90 & 100 & 94 & 85 & 77 & 80 \\
\hline MIS 13 & & 236 & 187 & & 168 & & & & 133 & 135 & 135 & 117 & 120 & & 123 & 110 & 102 & 101 & 96 \\
\hline MIS 15 & & 270 & & & & 167 & 153 & 166 & 166 & 155 & 156 & 153 & & 147 & 147 & 137 & 134 & 126 & 124 \\
\hline MIS 17c & & 302 & & & 193 & 204 & 194 & & 186 & & 185 & & & 165 & 164 & & 173 & 157 & \\
\hline MIS 19 & & 344 & & & & 245 & & & & 220 & 199 & 193 & & 171 & & 177 & & 179 & \\
\hline $\begin{array}{l}\text { Average uplift rate } \\
(\mathrm{mm} / \mathrm{a})\end{array}$ & 0.51 & 0.47 & 0.44 & 0.42 & 0.39 & 0.30 & 0.29 & 0.26 & 0.26 & 0.25 & 0.25 & 0.23 & 0.23 & 0.22 & 0.23 & 0.22 & 0.22 & 0.21 & 0.20 \\
\hline $\begin{array}{l}\text { Pediment minimum } \\
\text { elevation (masl) }\end{array}$ & & & & & & 600 & & & & 500 & & & & & 310 & & & & \\
\hline Possible age (ka) & & & & & & 2012 & & & & 1974 & & & & & 1341 & & & & \\
\hline Rasa top (masl) & & 345 & & 400 & & 320 & & & & 400 & & & 250 & & 120 & & & & \\
\hline Possible age (ka) & & 731 & & 951 & & 1073 & & & & 1579 & & & 1107 & & 519 & & & & \\
\hline
\end{tabular}






Figure 16. Shoreline angle elevation vs. distance to Arica (see Table 5 for the data); the circles indicate the data based on absolute ages (i.e., the bold numbers in Table 5). The bottom numbers indicate the average uplift rates in $\mathrm{mm} / \mathrm{a}$ (Table 5 and Table $S 1$ ). The uncertainty of shoreline angle elevations is estimated to $+/-5 \mathrm{~m}$ (see preceding). (B\&W print)

It is possible to perform a qualitative evaluation of the pediment abandonment time considering that the average uplift rates calculated using shorelines have been constant since the beginning of pediment incision. Between Ite and Ilo, pediments are observed at $310 \mathrm{~m}$ asl. Their age may be $1.3 \mathrm{Ma}$ considering

545 a $~ 0.23 \mathrm{~mm} / \mathrm{a}$ uplift rate (Table 5). Similarly, pediment surfaces were found at 400-450 m around Mollendo ( 1.9 Ma), and at $320 \mathrm{~m}$ near Pescadores ( 2.0 Ma, Table 5). In addition, the age of the rasa top may be close to $1 \mathrm{Ma}$ (Table 5 ). Note that these age assessments are only valid if the uplift rates have remained constant since 1 to $2 \mathrm{Ma}$. We discuss this hypothesis below and show that, in fact, the forearc uplift rates have been largely variable since the Upper Miocene.

\section{Discussion}

In this study, we observed uplifted fossil sea-cliffs and their rocky shore, usually located above relatively flat areas called terraces (or uplifted shores or abrasion surfaces). We find such geomorphic remnants all over the $500 \mathrm{~km}$ stretch of the Peruvian coastline from the Peru-Chile border (Arica) to Chala, confirming that this segment of the Peruvian coast is uplifting everywhere. We attempt to provide the chronology for these shorelines based on absolute ages (mostly ${ }^{10} \mathrm{Be}$ surface ages), and on the correlation between the terraces and the interglacial highstands. The sequences of raised shorelines seem to span the last 800 ka, at least. Over these raised and dated shoreline sequences, other uplifted shores are sometimes observed up to the characteristic continental landforms we called degradational landforms or pediments.

\section{1 ${ }^{10}$ Be data: uncertainties and erosion rates}

We propose a chronology established considering low erosion rates. The high ${ }^{10} \mathrm{Be}$ concentrations measured in IT6, indeed, demonstrate that erosion rates may be smaller than $10^{-6} \mathrm{~m} / \mathrm{a}$. In the southern 
cluster of samples (BR2, IT2 and IT6 sites), BR2 and IT2 are not of optimal quality due to a sedimentary cover and a morphological correlation at a fairly distant shoreline angle, respectively. If the ages have been underestimated (i.e., erosion rate approaching $10^{-6} \mathrm{~m} / \mathrm{a}$ ), an age for IT6 contemporary to MIS 15 or even MIS 17 cannot be excluded. It would then lead to a decrease in the uplift rate to 0.21 or $0.17 \mathrm{~mm} / \mathrm{a}$ respectively, which would not substantially change our conclusions. In the northern cluster of samples (CH1 and AT7 sites), we note that the ages in AT7 fit well with interglacial highstands (MIS 5e and MIS 7e) and thus suggest that a low erosion rate is likely. On the contrary, these ages are confusing because they do not follow the morphostratigraphic order. This suggests that complex covering/uncovering by sand dunes, for example, occurred in the area, but precisely tied to interglacials. Taken together, the $\mathrm{CH} 1$ and AT7 samples strengthen the previously established chronology in Chala Bay (Saillard, 2008).

In summary, the ${ }^{10} \mathrm{Be}$ data presented here are somewhat scattered but overall: (i) confirm that the erosion rates are low, usually less than $10^{-6} \mathrm{~m} / \mathrm{a}$; and (ii) fall within the age range adopted, which is morphostratigraphically adequate.

\subsection{Reference morphology and lateral variations from this reference}

Our observations along a $500 \mathrm{~km}$-long coastal stretch in southern Peru led us to propose a "reference" coastal sequence for the area. The reference sequence is best expressed in the central part of the study area, between Ite and Pescadores (100 to $400 \mathrm{~km}$ ). Sequences of the Pleistocene fossil rocky shoreline are raised up to $200 \mathrm{~m}$ asl, and include several marine terraces. Several coastal landforms and deposits are dated and correlated to Middle Pleistocene highstands such as those associated to MIS 13, 15 and 17 as observed elsewhere (Regard et al., 2017). Above the Middle Pleistocene dated shorelines, some remnants of marine terraces and rasa are observed alongshore but their record is too sparse to establish an accurate chronology. The upper strandlines are limited by the pediment surfaces that descend to $\sim 300-350 \mathrm{~m}$, depending on the location. A second pediment level is found at elevations between 450 and $700 \mathrm{~m}$ asl. These pediment surfaces are preserved only as remnants. Considering that these pediments correspond to gently dipping surfaces that were connected to the shoreline when they were active, their smallest presentday elevation can be used to infer a maximum amount of uplift. The spacing between the uppermost marine terrace and the lower pediment surfaces is often small; we interpret this as an evidence of either a slow average uplift between the end of the pediment activity and the oldest preserved terrace, or a small age difference, and that the lowest preserved pediment was close to sea level. We relate the lowest pediment surface to the $3 \mathrm{Ma}$-old surface described in the area (Evenstar et al., 2017). The lower pediment surface development coincides with the cessation of the incision of the canyons 2-3 Ma ago (Kober et al., 2006; Schildgen et al., 2007; Thouret et al., 2007; Schildgen et al., 2009b; Garcia et al., 2011). This agrees with the extrapolated age of $\sim 2 \mathrm{Ma}$ for the lower pediment, using a constant uplift rate (Table 5). The upper pediment surface would be then related to another older surface development period at $\sim 7 \mathrm{Ma}$ (Quang et al., 2005; Evenstar et al., 2017).

To the east (southeast) of the reference area, raised shorelines are found but rarely above $170 \mathrm{~m}$ asl. We did not detect fossil pediment surfaces, possibly because the current pediments are developing over the previous ones, due to the low amount of incision in the valleys (except around Arica, Kober et al., 2006, 2009), as observed in the Boca del Rio area and the Pampa de la Yarada in the in the heart of the Arica Bend. In this area, from llo to Boca del Rio, numerous faults are crossed. They affect paleosurfaces and should have been active since the Pliocene. However, they show minor displacements (Audin et al., 2008; Allmendinger and González, 2010; Garcia et al., 2011). Moreover, the continuity of the sequences of uplifted shorelines indicates a short wavelength effect, in line with the observed mean fault spacing of $\sim 10$ $\mathrm{km}$. In this study we consider these are second-order features. Nevertheless, the lower part of the sequence seems to be consistent with the reference sequence, albeit slightly lower (Figure 16). Thus, despite a 
somewhat lower rate of uplift, the morphological flatness of the area should instead be related to a lower slope (Martinod et al., 2016b) in the area when compared to the slope of the central part of the study area (Madella et al., 2016).

610 Tectonically speaking, the northwestern part of our study zone is influenced by the Nazca Ridge subduction (Goy et al., 1992; Machare and Ortlieb, 1992; Wipf et al., 2008; Regard et al., 2010; Saillard et al., 2011). The lower part of the sequence clearly records the subsequent increase in the uplift rate northwest from Pescadores (Figure 16). The area is also marked by a rasa, whose increasing width and elevation to the northwest have also been related to the Nazca Ridge subduction (Regard et al., 2010). The sparse remains

615 of the shoreline sequences over the rasa indicates it is older than MIS 11 in Chala whereas it emerged recently (less than $125 \mathrm{ka}$ ) southeast of Atico (Figure 13): clearly, the rasa uplift is not spatially synchronous. In some places such as Chala or Atico, the rasa is connected to wide valleys. Elsewhere, like in the Pescadores area, the rasa level is clearly lower than the uppermost raised cliffs (at $340 \mathrm{~m}$ asl), which are themselves found at a similar elevation as the lowermost pediments. This rasa position likely indicates a

620 stable (or slowly falling) relative sea level prior to the Quaternary uplift, as proposed in central-northern Chile by Rodriquez et al. (2013). However, this stability (or possibly subsidence) is only observed in this restricted zone of the study area, which is the only one under the influence of the Nazca Ridge. We know the uplift is due to the response of the upper plate to the subduction of the aseismic Nazca Ridge (see Espurt et al., 2007; Regard et al., 2009; Saillard et al., 2011; Martinod et al., 2013; Zeumann and Hampel,

625 2015; Martinod et al., 2016a). Therefore, one possible explanation for this transitory subsidence could be that, before its uplifting effect, the ridge has had a subsiding effect, which can be related to the deflection of the plate carrying it (as seen in the laboratory experiments of Martinod et al., 2013).

\subsection{Lithological and morphological controls on the preservation of fossil shores}

630 In southern Peru, raised fossil shores and cliffs are widespread. This is probably due to the arid climate reducing the onshore erosion. In terms of lithology, most of the coast is made up of intrusive rocks (the "coastal batholith"), and is therefore very resistant to erosion. On the one hand, it favors the conservation of landforms and the very low onshore erosion rates (often less than $1 \mathrm{~m} / \mathrm{Ma}$ ), which in turn are excellent for dating using cosmogenic nuclides $\left({ }^{10} \mathrm{Be}\right.$, cf. Table 2$)$. On the other hand, the shores are barely carved out by the sea and their footprint is not always clear, for instance in llo (Figure 9), Pescadores (Figure 11) and Aguada de la Zorra (Figure 12). Conversely, the Neogene sedimentary sequences found in Punta de Bombon (Figure 10) or Camana favor the development of coastal platforms; however, fossil shores are difficult to preserve.

At the main valley mouths, there is a complex interplay between the marine and fluvial terraces. As a result, it is not easy to understand the meaning of the "shoreline angle" due to significant deltaic sedimentation. This is the case in Ite (Figure 7) and Punta de Bombon (Figure 10). When the sediment discharge overfeeds the coastal area and covers the landforms, no uplift signal can be read (Pampa de la Yarada, Figure 5). Conversely, bays with a low sediment input appear to be a very good place for the building up of terrace sequences: this is the case for the well-known Chala Bay (Figure 14) (Goy et al., 1992; Saillard, 2008).

Apart from the lithology, it has been proposed that the pre-existing slope and the uplift rate are the main factors controlling the presence of uplifted shore sequences (e.g., Anderson et al., 1999; Trenhaile, 2002; Pedoja et al., 2014; Melnick, 2016; Martinod et al., 2016b). Steep slopes seem to lead to high scarps inhibiting the growth of marine terraces (Martinod et al., 2016b). Our record in southern Peru argues in this sense: the steepest area, around Pescadores and Ocoña, does not show many terraces. The rate of uplift affects the carving and conservation of the shoreline sequences: when low, it allows for the reoccupation 
of older shores (see Pedoja et al., 2014), or even the formation of a rasa (see Regard et al., 2010). A low uplift rate or subsidence also encourages the development of pediments onshore; the pediment surface may be connected to a rasa surface at the coast (Rodriguez et al., 2013).

\subsection{Long-term coast location stability}

655 A striking feature of this coast is its apparent stable position since $11 \mathrm{Ma}$. This is supported by two facts. First, Late Miocene deltaic sediments are found at the main river mouths (Camana and Punta de Bombon), indicating that the course of the rivers and the position of their mouths did not change much. Secondly, the width of the coastal strip hosting uplifted shores is narrow, usually less than $2 \mathrm{~km}$, implying a maximum oceanward motion of the shoreline of $\sim 1-2 \mathrm{~km} / \mathrm{Ma}$. In the context of an uplifting coast, this small shift towards the ocean is not counterbalanced by coastal retreat (or erosion, as emphasized by Malatesta et al., in press), except where the coast is steep, and where no old (>125 ka) terraces are preserved, like in Pescadores or in northern Chile (Martinod et al., 2016b).

One consequence of this is that the coast-trench distance did not vary a lot in the last $10 \mathrm{Ma}$, validating the recent proposition by Malatesta et al. (in press). The same holds true for the position of the coast with respect to the seismogenic zone on the subduction plane (downdip limit, Saillard et al., 2017), suggesting that the response of the coast to repeated seismic cycles has not changed much since $10 \mathrm{Ma}$ (Melnick, 2016; Saillard et al., 2017). Saillard et al. (2017) proposed that spatial variations in the seismogenic behavior along the Andean subduction zone are stationary over multiple seismic cycles and are reflected in the morphotectonic features of the forearc over geological timescales.

\section{7Б.5 Timing of uplift, uplift rates, and geodynamics}

In the reference area, the chronology drawn by our observations is determined by the following milestones. The top of the coastal cliff, corresponding to the 11 Ma-old Pampa surface, is between 850 and $1100 \mathrm{~m}$. A first uplift phase is detected at 11-8 Ma, through canyon incision and uplifted delta sediments (Quang et al., 2005; Kober et al., 2006; Schildgen et al., 2007, 2009a; Garcia et al., 2011; Alván and von Eynatten, 2014; Evenstar et al., 2017). A new pediment surface lying at elevations between 450 and $700 \mathrm{~m}$ asl developed at $\sim 7 \mathrm{Ma}$ (Quang et al., 2005; Evenstar et al., 2017), suggesting a pause in the forearc uplift. Then, the 11-8 Ma uplift phase corresponds to uplift rates of $\sim 0.13 \pm 0.11 \mathrm{~mm} / \mathrm{a}$. A second uplift is recorded between 7 and 5 Ma followed by another period of interrupted uplift evidenced by the 3 Ma-old surface, now found at elevations ranging from $\sim 300$ to $\sim 350 \mathrm{~m}$ asl. The second uplift phase average uplift rate is $\sim 0.12 \pm 0.12$ $\mathrm{mm} / \mathrm{a}$. This period is contemporaneous with the fossilization of the uppermost sea cliffs. After some time of quiescence, marked by 2-3 Ma-old lava flows in canyons (Schildgen et al., 2007; Thouret et al., 2007; Schildgen et al., 2009a; Garcia et al., 2011), a renewal of uplift has been occurring since 1 to $2 \mathrm{Ma}$ at relatively continuous uplift rates of 0.20 to $0.25 \mathrm{~mm} / \mathrm{a}$ on average. This velocity is well constrained by raised marine terraces (Figure 16 and Table 5), and has been accelerated ( $x 1.5)$ to the northwest by the subduction of the Nazca Ridge (Figure 17). The uplift rate in southern Peru is slightly higher than the one proposed by Melnick (2016) in Chile from a landscape evolution model, but similar to the one observed in northern Chile by Martinod et al. (2016b). Figure 17 summarizes these observations.

The analysis of the coastal morphology suggests that the uplift of the southern Peru forearc has been sporadic since $11 \mathrm{Ma}$ (Figure 17), with periods of uplift alternating with periods of quiescence (and possibly subsidence) during which wide degradation surfaces developed. The estimated uplift rates that we calculated for the uplifting phases are averages over the uplift periods, except for the ultimate period $(<800$ $\mathrm{ka})$, which resulted in a regularly spaced raised shoreline constituting the Pleistocene coastal sequence. The duration of the older uplift episodes are not precisely constrained, and the uplift rates may approach 0.1 or 

stability, like the $\sim 5-2.5$ Ma period (Figure 17).

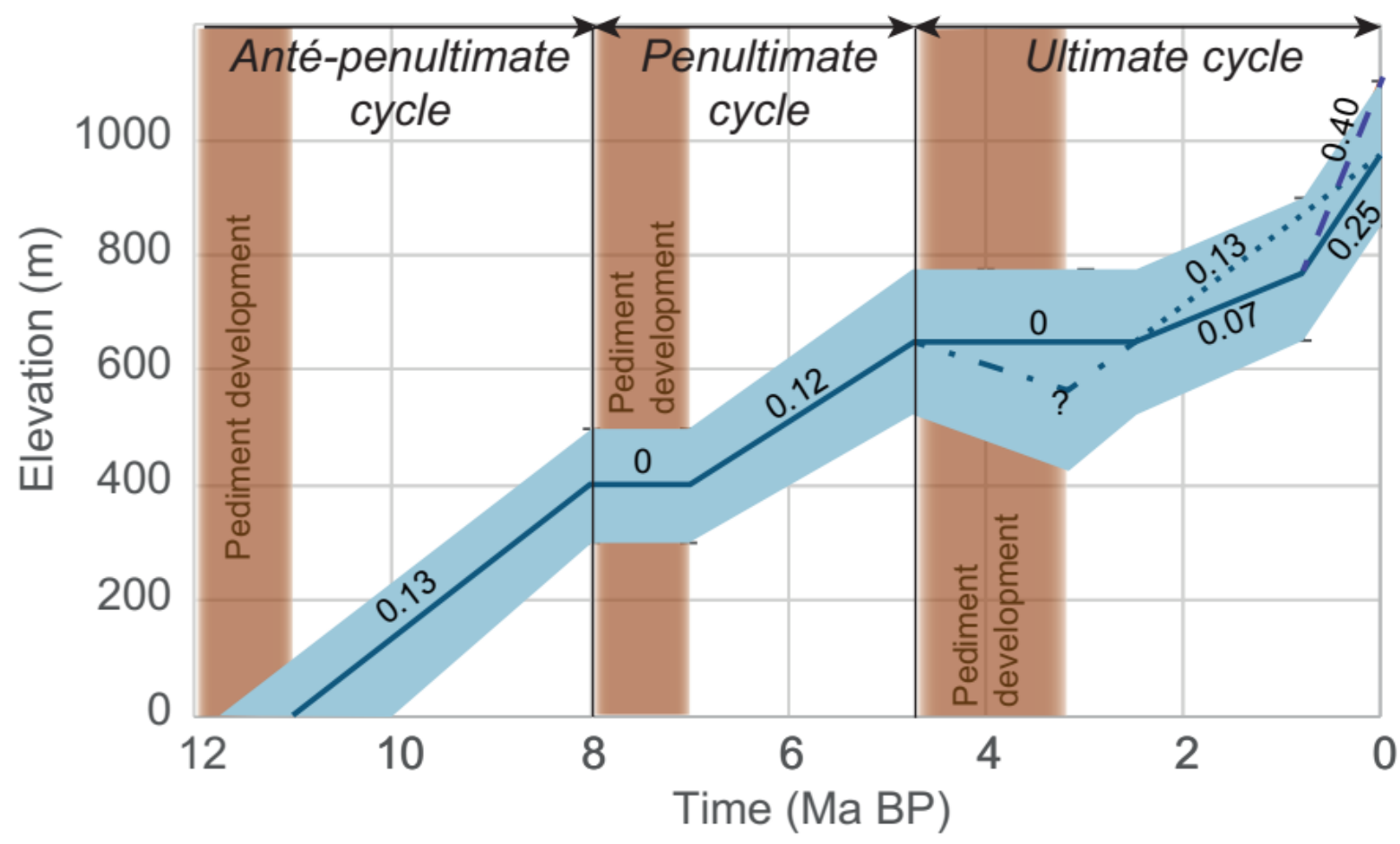

Figure 17. Inferred uplift of the 11 Ma-old pediment surface in southern Peru. The numbers indicate the uplift rate $(\mathrm{mm} / \mathrm{a})$. The dashed line corresponds to the Chala site where we suspect an additional uplift due to the subduction of the Nazca Ridge. The dotted line corresponds to the average uplift rate for the last $2.5 \mathrm{Ma}$. The dashed and dotted line represents the possibility of subsidence rather than stability between uplift periods. This graph shows $\sim 4 \mathrm{Ma}$-long cycles of alternating periods of uplift (average velocity of $\sim 0.1 \mathrm{~mm} / \mathrm{a}$, but possibly faster during short periods) and periods of stability (if not subsidence). Note that our time resolution cannot be used to determine the uplift velocity evolution on the Ma scale, except for the ultimate cycle documented in this study. (B\&W print)

The uplift has been related to the accumulation of an elastic deformation during seismic cycles (e.g., Song and Simons, 2003; Mouslopoulou et al., 2016; Melnick, 2016; Saillard et al., 2017; Jolivet et al., 2020). Jolivet et al. (2020) show that the uplift is less rapid where faults are present (all types of faulting: reverse, normal, and strike slip), either because they help to dissipate the stress that accumulates in the forearc during interseismic loading or because they reflect some differences in terms of mechanical behavior. These observations satisfactorily explain the southeastward decrease in the uplift rates observed in the Arica Bend, where the fault density is higher than elsewhere in the study area (Audin et al., 2008; Allmendinger and González, 2010; Garcia et al., 2011).

The numerical models developed by Menant et al. (2020) suggest that the discontinuous forearc uplift may result from the tectonic underplating of materials accreted at the base of the overriding plate. Their models suggest indeed that the tectonic underplating is not continuous, resulting in a pulsed forearc uplift similar to what our observations suggest in this area. The models provided by Menant et al. (2020) predict a $\sim 2.8$ Ma-periodicity in the forearc uplift cycles for a convergence rate of $50 \mathrm{~mm} / \mathrm{a}$. The period decreases with an increasing convergence rate; on the contrary, no periodic uplift is observed for slower convergence. The periodic behavior we observe agrees remarkably well with the results of Menant et al. (2020), with a slightly longer time period ( $\sim \mathrm{Ma}$ in our case). If the signal we observe marks the slab stripping described by Menant et al. (2020), periods of subsidence may occur between the uplift phases. Such periods could be illustrated by the transgressions documented in south Peru forearc basins during the Upper Miocene (Pena 
et al., 2004). The ultimate subsidence period occurred during the Plio-Quaternary: Upper and Middle Pleistocene marine terraces are found at higher altitudes than the late Pliocene lava flows filling deep canyons, confirming that a moderate subsidence preceded the ultimate and ongoing uplift episode.

\section{Conclusions}

The $500 \mathrm{~km}$-long coastal segment between Chala and Arica (southern Peru) shows evidence of uplift in the form of raised shorelines (up to $300 \mathrm{~m}$ asl) and sea cliffs, as well as continental landforms (pediments). On the basis of a geomorphological analysis of the geographical and vertical disposition of these timed landforms and on data from the literature and new ${ }^{10} \mathrm{Be}$ ages, we propose the following chronology for the last $12 \mathrm{Ma}$. Three periods of coastal stability or subsidence occurred $\sim 12-11 \mathrm{Ma}, \sim 8-7 \mathrm{Ma}$ and $\sim 5-2.5 \mathrm{Ma}$ ago. They are recorded along the Peruvian coast by pediments hanging over the coastal escarpment. Between these periods, the coast uplifted. For the last period of uplift only, during the last $800 \mathrm{ka}$, the forearc uplift has been accurately recorded by the carving of numerous coastal sequences. Within these sequences, we correlate the marine terraces to sea level highstands (interglacials stages and sub-stages) up to MIS 19 (790 ka), i.e., with a resolution of $\sim 100 \mathrm{ka}$.

The record is fairly constant along the study area, and the landforms corresponding to the three successive periods of coastal stability are found at 850-1100, 450-700 and 300-350 m asl. The last period of uplift is well constrained by marine terraces, and the vertical velocity increases westward from $0.20 \pm 0.04 \mathrm{~mm} / \mathrm{a}$ in 740 the Arica Bend to $0.30 \pm 0.05 \mathrm{~mm} / \mathrm{a}$ near Ocoña/Pescadores and 0.49 $\pm 0.10 \mathrm{~mm} / \mathrm{a}$ at Chala. The increase in the uplift rate from Pescadores to Chala is due to the subduction of the Nazca Ridge (e.g., Machare and Ortlieb, 1992; Wipf et al., 2008; Regard et al., 2010; Saillard et al., 2011). Away from the Nazca Ridge, the uplift rates are similar to those recorded along the coast of northern Chile $(0.13 \pm 0.04 \mathrm{~mm} / \mathrm{a}$, Melnick, 2016; $0.28 \pm 0.15 \mathrm{~mm} / \mathrm{a}$, Martinod et al., 2016b). During previous uplift periods ( 11-8 Ma and 7-5 Ma)

745 the coast has probably uplifted by $>0.1 \mathrm{~mm} / \mathrm{a}$, possibly up to $0.2 \mathrm{~mm} / \mathrm{a}$, equivalent to the modern uplift rate.

In this study, we document an unusual $\sim 4 \mathrm{Ma}$-long cyclic forearc uplift. This periodicity matches the predictions made by Menant et al. (2020) based on numerical models, suggesting it may be related to episodic tectonic underplating (subducting slab stripping) beneath the coastal forearc area.

\section{Acknowledgments}

This work has been funded by the French Institut National des Sciences de I'Univers (CNRS) through the Syster program, by the DLR (German Aerospace Center) through the TanDEM-X DEM delivery (project DEM_GEOL1344). The Institut de Recherche pour le Developpement (IRD) provided support for field trips. We would like to thank the ASTER Team for its technical support and the ${ }^{10} \mathrm{Be}$ concentration measurements (see Arnold et al., 2010). R. Riquelme is acknowledged for fruitful discussions. The maps and graphs were drawn using QGIS, and R, with its extension ggplot2, respectively. We are grateful to Sara Mulin for correcting the English. Competing interests: The authors declare that they have no competing interests.

\section{References}

Allmendinger, R.W., and González, G., 2010, Invited review paper: Neogene to Quaternary tectonics of the coastal Cordillera, northern Chile: Tectonophysics, v. 495, p. 93-110, doi:10.1016/j.tecto.2009.04.019. 
Allmendinger, R.W., Gonzalez, G., Yu, J., Hoke, G., and Isacks, B., 2005, Trench-parallel shortening in the Northern Chilean Forearc: Tectonic and climatic implications: Geological Society Of America Bulletin, v. 117, p. 89-104.

Alván, A., and von Eynatten, H., 2014, Sedimentary facies and stratigraphic architecture in coarse-grained deltas: Anatomy of the Cenozoic Camaná Formation, southern Peru $\left(16^{\circ} 25^{\prime} \mathrm{S}\right.$ to $\left.17^{\circ} 15^{\prime} \mathrm{S}\right)$ : Journal of South American Earth Sciences, v. 54, p. 82-108, doi:10.1016/j.jsames.2014.04.008.

Alvarez-Marron, J., Hetzel, R., Niedennann, S., Menendez, R., and Marquinez, J., 2008, Origin, structure and exposure history of a wave-cut platform more than $1 \mathrm{Ma}$ in age at the coast of northern Spain: $\mathrm{A}$ multiple cosmogenic nuclide approach: Geomorphology, v. 93, p. 316-334.

Anderson, R.S., Densmore, A.L., and Ellis, M.A., 1999, The generation and degradation of marine terraces: Basin Research, v. 11, p. 7-19.

Arnold, M., Merchel, S., Bourlès, D.L., Braucher, R., Benedetti, L., Finkel, R.C., Aumaître, G., Gottdang, A., and Klein, M., 2010, The French accelerator mass spectrometry facility ASTER: Improved performance and developments: Nuclear Instruments and Methods in Physics Research Section B: Beam Interactions with Materials and Atoms, v. 268, p. 1954-1959, doi:10.1016/j.nimb.2010.02.107.

Audin, L., Lacan, P., Tavera, H., and Bondoux, F., 2008, Upper plate deformation and seismic barrier in front of Nazca subduction zone: The Chololo Fault System and active tectonics along the Coastal Cordillera, southern Peru: Tectonophysics, v. 459, p. 174-185.

Bellido, E., and Guevara, C., 1963, Geologia del cuadrangolo de Punta de Bombon y Clemensi: Comision Carta Geologica Nacional, v. 5, p. 10-55.

Binnie, S.A. et al., 2020, The origins and implications of paleochannels in hyperarid, tectonically active regions: The northern Atacama Desert, Chile: Global and Planetary Change, v. 185, p. 103083, doi:10.1016/j.gloplacha.2019.103083.

Binnie, A., Dunai, T.J., Binnie, S.A., Victor, P., González, G., and Bolten, A., 2016, Accelerated late quaternary uplift revealed by $10 \mathrm{Be}$ exposure dating of marine terraces, Mejillones Peninsula, northern Chile: Quaternary Geochronology, v. 36, p. 12-27, doi:10.1016/j.quageo.2016.06.005.

Braucher, R., Guillou, V., Bourlès, D.L., Arnold, M., Aumaître, G., Keddadouche, K., and Nottoli, E., 2015, Preparation of ASTER in-house 10Be/9Be standard solutions: Nuclear Instruments and Methods in Physics Research Section B: Beam Interactions with Materials and Atoms, v. 361, p. 335-340, doi:10.1016/j.nimb.2015.06.012.

Caputo, R., 2007, Sea-level curves: Perplexities of an end-user in morphotectonic applications: Global And Planetary Change, v. 57, p. 417-423.

Carretier, S., Tolorza, V., Regard, V., Aguilar, G., Bermúdez, M.A., Martinod, J., Guyot, J.-L., Hérail, G., and Riquelme, R., 2018, Review of erosion dynamics along the major N-S climatic gradient in Chile and perspectives: Geomorphology, v. 300, p. 45-68, doi:10.1016/j.geomorph.2017.10.016.

Chappell, J., 1974, The Geomorphology and Evolution of Small Valleys in Dated Coral Reef Terraces, New Guinea: The Journal of Geology, v. 82, p. 795-812, doi:10.1086/628030. Antiquity of a Rocky Shore Platform on the West Coast of Korea: Journal of Coastal Research, v. 282, p. 641-657, doi:10.2112/JCOASTRES-D-11-00087.1. 
Clark, J.A., Farrell, W.E., and Peltier, W.R., 1978, Global changes in postglacial sea level: A numerical calculation: Quaternary Research, v. 9, p. 265-287, doi:10.1016/0033-5894(78)90033-9.

805 Costa, C. et al., 2020, Hazardous faults of South America; compilation and overview: Journal of South American Earth Sciences, v. 104, p. 102837, doi:10.1016/j.jsames.2020.102837.

Cruzado, H., and Rojas, A., 2005, Incursión marina en una cuenca continental de ante arco: Eustatismo o tectónica? El ejemplo de la cuenca Moquegua. Universidad San Antonio de Abad del Cuzco (Perú):

Cutler, K.B., Edwards, R.L., Taylor, F.W., Cheng, H., Adkins, J., Gallup, C.D., Cutler, P.M., Burr, G.S., and Bloom, A.L., 2003, Rapid sea-level fall and deep-ocean temperature change since the last interglacial period: Earth and Planetary Science Letters, v. 206, p. 253-271.

DeMets, C., Gordon, R.G., and Argus, D.F., 2010, Geologically current plate motions: Geophysical Journal International, v. 181, p. 1-80, doi:10.1111/j.1365-246X.2009.04491.x.

DeVries, T., 1998, Oligocene deposition and Cenozoic sequence boundaries in the Pisco Basin (Peru): Journal of South American Earth Sciences, v. 11, p. 217-231.

Dunai, T.J., Lopez, G.A.G., and Juez-Larre, J., 2005, Oligocene-Miocene age of aridity in the Atacama Desert revealed by exposure dating of erosion-sensitive landforms: Geology, v. 33, p. 321-324.

Espurt, N., Baby, P., Brusset, S., Roddaz, M., Hermoza, W., Regard, V., Antoine, P.-O., Salas-Gismondi, R., and Bolaños, R., 2007, How does the Nazca Ridge subduction influence the modern Amazonian foreland basin? Geology, v. 35, p. 515, doi:10.1130/G23237A.1.

Evenstar, L.A., Mather, A.E., Hartley, A.J., Stuart, F.M., Sparks, R.S.J., and Cooper, F.J., 2017, Geomorphology on geologic timescales: Evolution of the late Cenozoic Pacific paleosurface in Northern Chile and Southern Peru: Earth-Science Reviews, v. 171, p. 1-27, doi:10.1016/j.earscirev.2017.04.004.

Evenstar, L.A., Stuart, F.M., Hartley, A.J., and Tattitch, B., 2015, Slow Cenozoic uplift of the western Andean Cordillera indicated by cosmogenic ${ }^{3} \mathrm{He}$ in alluvial boulders from the Pacific Planation Surface: SLOW CENOZOIC UPLIFT OF THE ANDES: Geophysical Research Letters, v. 42, p. 8448-8455, doi:10.1002/2015GL065959.

Garcia, M., and Herail, G., 2005, Fault-related folding, drainage network evolution and valley incision during the Neogene in the Andean Precordillera of Northern Chile: Geomorphology, v. 65, p. 279-300.

Garcia, M., Riquelme, R., Farias, M., Hérail, G., and Charrier, R., 2011, Late Miocene-Holocene canyon incision in the western Altiplano, northern Chile : tectonic or climatic forcing ? Journal of the Geological Society, v. 168, p. 1047-1060, doi:10.1144/0016-76492010-134.

Garzione, C.N., Hoke, G.D., Libarkin, J.C., Withers, S., MacFadden, B., Eiler, J., Ghosh, P., and Mulch, A., 2008, Rise of the Andes: Science, v. 320, p. 1304-1307, doi:10.1126/science.1148615.

835 Garzione, C.N., McQuarrie, N., Perez, N.D., Ehlers, T.A., Beck, S.L., Kar, N., Eichelberger, N., Chapman, A.D., Ward, K.M., and Ducea, M.N., 2017, Tectonic evolution of the Central Andean plateau and implications for the growth of plateaus: Annual Review of Earth and Planetary Sciences, v. 45, p. 529-559.

de Gelder, G., Jara-Muñoz, J., Melnick, D., Fernández-Blanco, D., Rouby, H., Pedoja, K., Husson, L., Armijo, R., and Lacassin, R., 2020, How do sea-level curves influence modeled marine terrace sequences? Quaternary Science Reviews, v. 229, p. 106132, doi:10.1016/j.quascirev.2019.106132. 
Gonzalez, G., Cembrano, J., Carrizo, D., Macci, A., and Schneider, H., 2003, The link between forearc tectonics and Pliocene-Quaternary deformation of the Coastal Cordillera, northern Chile: Journal of South American Earth Sciences, v. 16, p. 321-342.

Goy, J., Machare, J., Ortlieb, L., and Zazo, C., 1992, Quaternary shorelines in southern Peru: A record of global sea-level fluctuations and tectonic uplift in Chala Bay: Quaternary International, v. 15-16, p. 99.

Guilcher, A., 1974, Les "rasas": Un problème de morphologie littorale générale: Annales de Géographie, v. 455, p. 1-33.

Hall, S.R., Farber, D.L., Audin, L., Finkel, R.C., and Mériaux, A.-S., 2008, Geochronology of pediment surfaces in southern Peru: Implications for Quaternary deformation of the Andean forearc: Tectonophysics, v. 459, p. 186-205, doi:10.1016/j.tecto.2007.11.073.

Hall, S.R., Farber, D.L., Audin, L., and Mériaux, A.-S., 2005, Forearc deformation of the Peruvian margin : Quantifying the rates of Quaternary deformation in pediment surfaces using in situ-produced cosmogenic 10Be and 26Al, in 6th International Symposium on Andean Geodynamics, Barcelona, IRD, p. 358-359.

Hsu, J.T., Leonard, E.M., and Wehmiller, J.F., 1989, Aminostratigraphy of Peruvian and Chilean Quaternary marine terraces: Quaternary Science Reviews, v. 8, p. 255-262.

Hurst, M.D., Rood, D.H., Ellis, M.A., Anderson, R.S., and Dornbusch, U., 2016, Recent acceleration in coastal cliff retreat rates on the south coast of Great Britain: Proceedings of the National Academy of Sciences, v. 113, p. 13336-13341, doi:10.1073/pnas.1613044113.

INGEMMET, 1999, Geological Map of Peru.:

Jara-Muñoz, J., and Melnick, D., 2015, Unraveling sea-level variations and tectonic uplift in wave-built marine terraces, Santa María Island, Chile: Quaternary Research, v. 83, p. 216-228, doi:10.1016/j.yqres.2014.10.002.

Jara-Muñoz, J., Melnick, D., and Strecker, M.R., 2016, TerraceM: A MATLAB ${ }^{\circledR}$ tool to analyze marine and lacustrine terraces using high-resolution topography: Geosphere, v. 12, p. 176-195, doi:10.1130/GES01208.1.

Jolivet, R., Simons, M., Duputel, Z., Olive, J. -A., Bhat, H.S., and Bletery, Q., 2020, Interseismic Loading of Subduction Megathrust Drives Long-Term Uplift in Northern Chile: Geophysical Research Letters, v. 47, doi:10.1029/2019GL085377.

Jordan, T.E., Nester, P.L., Blanco, N., Hoke, G.D., Davila, F., and Tomlinson, A.J., 2010, Uplift of the AltiplanoPuna plateau: A view from the west: Tectonics, v. 29, p. TC5007, doi:10.1029/2010TC002661.

Kim, K.J., and Sutherland, R., 2004, Uplift rate and landscape development in southwest Fiordland, New Zealand, determined using $10 \mathrm{Be}$ and $26 \mathrm{Al}$ exposure dating of marine terraces: Geochimica et Cosmochimica Acta, v. 68, p. 2313.

Kober, F., Ivy-Ochs, S., Zeilinger, G., Schlunegger, F., Kubik, P.W., Baur, H., and Wieler, R., 2009, Complex multiple cosmogenic nuclide concentration and histories in the arid Rio Lluta catchment, northern Chile: Earth Surface Processes And Landforms, v. 34, p. 398-412. geomorphic evolution of the Western Escarpment of the Andes of northern Chile between the 
Miocene and present, in Willett, S.D., Hovius, N., Brandon, M.T., and Fisher, D.M. eds., Tectonics, Climate, and Landscape Evolution, v. 398, p. 75-86.

Kong, P., Na, C., Brown, R., Fabel, D., Freeman, S., Xiao, W., and Wang, Y., 2011, Cosmogenic 10Be and 26Al dating of paleolake shorelines in Tibet: Journal of Asian Earth Sciences, v. 41, p. 263-273, doi:10.1016/j.jseaes.2011.02.016.

Lajoie, K.R., 1986, Coastal Tectonics, in Active Tectonics Impact on Society, Washington D.C., Nat. Academy Press.

Lal, D., 1991, Cosmic ray labeling of erosion surfaces: in-situ nuclide production rates and erosion models: Earth Planet. Sci. Lett., v. 104, p. 424-439.

Macharé, J., DeVries, T., Barron, J., and Fourtanier, E., 1988, Oligo-Miocene transgression along the Pacific margin of South America: new paleontological and geological evidence from the Pisco basin (Peru): Géodynamique, v. 3, p. 25-37.

Machare, J., and Ortlieb, L., 1992, Plio-Quaternary vertical motions and the subduction of the Nazca Ridge, central coast of Peru: Tectonophysics, v. 205, p. 97.

Madella, A., Delunel, R., Audin, L., and Schlunegger, F., 2016, Why is there no Coastal Cordillera at the Arica Bend (Western Central Andes)? Basin Research, p. n/a-n/a, doi:10.1111/bre.12218.

Madella, A., Delunel, R., Oncken, O., Szidat, S., and Schlunegger, F., 2017, Transient uplift of a long-term quiescent coast inferred from raised fan delta sediments: Lithosphere, v. 9, p. 796-802, doi:10.1130/L659.1.

Malatesta, L.C., Bruhat, L., Finnegan, N.J., and Olive, J.-A.L., in press, Co-location of the downdip end of seismic coupling and the continental shelf break: Journal of Geophysical Research: Solid Earth, v. n/a, p. e2020JB019589, doi:https://doi.org/10.1029/2020JB019589.

Martinod, J., Gérault, M., Husson, L., and Regard, V., 2020, Widening of the Andes: An interplay between subduction dynamics and crustal wedge tectonics: Earth-Science Reviews, p. 103170, doi:10.1016/j.earscirev.2020.103170.

Martinod, J., Guillaume, B., Espurt, N., Faccenna, C., Funiciello, F., and Regard, V., 2013, Effect of aseismic ridge subduction on slab geometry and overriding plate deformation: Insights from analogue modeling: Tectonophysics, v. 588, p. 39-55, doi:10.1016/j.tecto.2012.12.010.

Martinod, J., Regard, V., Letourmy, Y., Henry, H., Hassani, R., Baratchart, S., and Carretier, S., 2016a, How do subduction processes contribute to forearc Andean uplift? Insights from numerical models: Journal of Geodynamics, v. 96, p. 6-18, doi:10.1016/j.jog.2015.04.001.

Martinod, J., Regard, V., Riquelme, R., Aguilar, G., Guillaume, B., Carretier, S., Cortes-Aranda, J., Leanni, L., and Herail, G., 2016b, Pleistocene uplift, climate and morphological segmentation of the Northern Chile coasts (24 degrees S-32 degrees S): Insights from cosmogenic Be-10 dating of paleoshorelines: Geomorphology, v. 274, p. 78-91, doi:10.1016/j.geommph.2016.09.010.

Melnick, D., 2016, Rise of the central Andean coast by earthquakes straddling the Moho: Nature Geoscience, v. 9, p. 401-+, doi:10.1038/NGEO2683.

Melnick, D., Bookhagen, B., Echtler, H.P., and Strecker, M.R., 2006, Coastal deformation and great subduction earthquakes, Isla Santa Maria, Chile (37 S): Geological Society of America Bulletin, v. 118, p. 1463-1480, doi:10.1130/B25865.1. 
Melnick, D., Bookhagen, B., Strecker, M.R., and Echtler, H.P., 2009, Segmentation of megathrust rupture zones from fore-arc deformation patterns over hundreds to millions of years, Arauco peninsula, Chile: Journal of Geophysical Research, v. 114, doi:10.1029/2008JB005788.

Menant, A., Angiboust, S., Gerya, T., Lacassin, R., Simoes, M., and Grandin, R., 2020, Transient stripping of subducting slabs controls periodic forearc uplift: Nature Communications, v. 11, doi:10.1038/s41467-020-15580-7.

Mouslopoulou, V., Oncken, O., Hainzl, S., and Nicol, A., 2016, Uplift rate transients at subduction margins due to earthquake clustering: Tectonics, v. 35, p. 2370-2384, doi:10.1002/2016TC004248.

Noble, D.C., Sébrier, M., Megard, F., and McKee, E.H., 1985, Demonstration of two pulses of Paleogene deformation in the Andes of Peru: Earth and Planetary Science Letters, v. 73, p. 345-349.

Ortlieb, L., Ghaleb, B., Hillaire-Marcel, C., Machare, J., and Pichet, P., 1992, Déséquilibres U/Th, rapports allo/isoleucine et teneurs en 180 des mollusques de dépôts littoraux pléistocénes du sud du Pérou: une base d'appréciation chronostratigraphique: Comptes Rendus De L'Academie Des Sciences Paris, v. 314, p. 101-107.

Ortlieb, L., Zazo, C., Goy, J.L., Dabrio, C., and Machare, J., 1996, Pampa del Palo: An anomalous composite marine terrace on the uprising coast of southern Peru: Journal Of South American Earth Sciences, v. 9, p. 367-379.

Past Interglacials Working Group of PAGES, 2016, Interglacials of the last 800,000 years: Reviews of Geophysics, p. 2015RG000482, doi:10.1002/2015RG000482.

Pavlis, N.K., Holmes, S.A., Kenyon, S.C., and Factor, J.K., 2012, The development and evaluation of the Earth Gravitational Model 2008 (EGM2008): Journal of Geophysical Research: Solid Earth, v. 117, doi:https://doi.org/10.1029/2011JB008916.

Pedoja, K. et al., 2014, Coastal staircase sequences reflecting sea-level oscillations and tectonic uplift during the Quaternary and Neogene: Earth-Science Reviews, v. 132, p. 13-38, doi:10.1016/j.earscirev.2014.01.007.

Pedoja, K. et al., 2011, Relative sea-level fall since the last interglacial stage: Are coasts uplifting worldwide? Earth-Science Reviews, v. 108, p. 1-15, doi:16/j.earscirev.2011.05.002.

Pedoja, K., Ortlieb, L., Dumont, J.F., Lamothe, M., Ghaleb, B., Auclair, M., and Labrousse, B., 2006, Quaternary coastal uplift along the Talara Arc (Ecuador, Northern Peru) from new marine terrace data: Marine Geology, v. 228, p. 73-91.

Pena, F.D., Apolin, J., Rodriguez, B., and Sempéré, T., 2004, Estudio preliminar de los depósitos deltaicos miocenos del río Tambo (Punta de Bombón, Arequipa):

Perg, L.A., Anderson, R.S., and Finkel, R.C., 2001, Use of a new Be-10 and Al-26 inventory method to date marine terraces, Santa Cruz, California, USA: Geology, v. 29, p. 879-882.

Phillips, F.M. et al., 2016, The CRONUS-Earth Project: A synthesis: Quaternary Geochronology, v. 31, p. 119154, doi:10.1016/j.quageo.2015.09.006.

Pillans, B., 1983, Upper Quaternary marine terrace chronology and deformation, South Taranaki, New Zealand: Geology, v. 11, p. 292-297. 

Cenozoic uplift, pediment erosion, and ignimbrite eruption in the porphyry copper province of southern Peru: Economic Geology, v. 100, p. 87-114, doi:10.2113/100.1.0087.

Quezada, J., Gonzalez, G., Dunai, T., Jensen, A., and Juez-Larre, J., 2007, Pleistocene littoral uplift of northern Chile: Ne-21 age of the upper marine terrace of Caldera-Bahia Inglesa area: Revista Geologica De Chile, v. 34, p. 81-96.

Raimbault, C., Duperret, A., Regard, V., Molliex, S., Wyns, R., Authemayou, C., and Le Gall, B., 2018, Quaternary geomorphological evolution of a granitic shore platform constrained by in situ 10Be concentrations, Penmarc'h, SW Brittany, France: Marine Geology, v. 395, p. 33-47, doi:10.1016/j.margeo.2017.09.011.

Regard, V., Dewez, T., Bourlès, D.L., Anderson, R.S., Duperret, A., Costa, S., Leanni, L., Lasseur, E., Pedoja, K., and Maillet, G.M., 2012, Late Holocene seacliff retreat recorded by $10 B e$ profiles across a coastal platform: Theory and example from the English Channel: Quaternary Geochronology, v. 11, p. 8797, doi:10.1016/j.quageo.2012.02.027.

Regard, V., Lagnous, R., Espurt, N., Darrozes, J., Baby, P., Roddaz, M., Calderon, Y., and Hermoza, W., 2009, Geomorphic evidence for recent uplift of the Fitzcarrald Arch (Peru): A response to the Nazca Ridge subduction: Geomorphology, v. 107, p. 107-117, doi:10.1016/j.geomorph.2008.12.003.

Regard, V., Pedoja, K., De La Torre, I., Saillard, M., Cortés-Aranda, J., and Nexer, M., 2017, Geometrical trends within sequences of Pleistocene marine terraces: selected examples from California, Peru, Chile and New-Zealand: Zeitschrift f??r Geomorphologie, v. 61, p. 53-73, doi:10.1127/zfg/2017/0389.

Regard, V., Saillard, M., Martinod, J., Audin, L., Carretier, S., Pedoja, K., Riquelme, R., Paredes, P., and Hérail, G., 2010, Renewed uplift of the Central Andes Forearc revealed by coastal evolution during the Quaternary: Earth and Planetary Science Letters, v. 297, p. 199-210, doi:10.1016/j.epsl.2010.06.020.

Rodriguez, M.P., Carretier, S., Charrier, R., Saillard, M., Regard, V., Herail, G., Hall, S., Farber, D., and Audin, L., 2013, Geochronology of pediments and marine terraces in north-central Chile and their implications for Quaternary uplift in the Western Andes: Geomorphology, v. 180, p. 33-46, doi:10.1016/j.geomorph.2012.09.003.

Roperch, P., Sempere, T., Macedo, O., Arriagada, C., Fornari, M., Tapia, C., Garcia, M., and Laj, C., 2006, Counterclockwise rotation of late Eocene-Oligocene fore-arc deposits in southern Peru and its significance for oroclinal bending in the central Andes: Tectonics, v. 25.

Saillard, M., 2008, Dynamique du soulèvement côtier Pléistocène des Andes centrales : Etude de l'évolution géomorphologique et datations (10Be) de séquences de terrasses marines (Sud Pérou - Nord Chili): Université de Toulouse.

Saillard, M., Audin, L., Rousset, B., Avouac, J.-P., Chlieh, M., Hall, S.R., Husson, L., and Farber, D.L., 2017, From the seismic cycle to long-term deformation: linking seismic coupling and Quaternary coastal geomorphology along the Andean megathrust: Interseismic Coupling/Coastal Morphology: Tectonics, v. 36, p. 241-256, doi:10.1002/2016TC004156.

Saillard, M., Hall, S.R., Audin, L., Farber, D.L., Hérail, G., Martinod, J., Regard, V., Finkel, R.C., and Bondoux, F., 2009, Non-steady long-term uplift rates and Pleistocene marine terrace development along the Andean margin of Chile $\left(31^{\circ} \mathrm{S}\right)$ inferred from 10Be dating: Earth and Planetary Science Letters, v. 277 , p. 50. 
Saillard, M., Hall, S.R., Audin, L., Farber, D.L., Regard, V., and Hérail, G., 2011, Andean coastal uplift and active tectonics in southern Peru: 10Be surface exposure dating of differentially uplifted marine terrace sequences (San Juan de Marcona, 15.4 ${ }^{\circ}$ S): Geomorphology, v. 128, p. 178-190, doi:10.1016/j.geomorph.2011.01.004.

Saillard, M., Riotte, J., Regard, V., Violette, A., Hérail, G., Audin, L., and Riquelme, R., 2012, Beach ridges UTh dating in Tongoy bay and tectonic implications for a peninsula-bay system, Chile: Journal of South American Earth Sciences, v. 40, p. 77-84, doi:10.1016/j.jsames.2012.09.001.

1010

1015

1020

1025

1030

1035

Schildgen, T.F., Ehlers, T.A., Whipp, D.M., van Soest, M.C., Whipple, K.X., and Hodges, K.V., 2009a, Quantifying canyon incision and Andean Plateau surface uplift, southwest Peru: A thermochronometer and numerical modeling approach: Journal Of Geophysical Research-Earth Surface, v. 114.

Schildgen, T.F., Hodges, K.V., Whipple, K.X., Pringle, M.S., van Soest, M., and Cornell, K., 2009b, Late Cenozoic structural and tectonic development of the western margin of the central Andean Plateau in southwest Peru: Tectonics, v. 28.

Schildgen, T.F., Hodges, K.V., Whipple, K.X., Reiners, P.W., and Pringle, M.S., 2007, Uplift of the western margin of the Andean plateau revealed from canyon incision history, southern Peru: Geology, $v$. 35, p. 523-526.

Sebrier, M., Mercier, J.L., Machare, J., Bonnot, D., Cabrera, J., and Blanc, J.L., 1988, The State Of Stress In An Overriding Plate Situated Above A Flat Slab - The Andes Of Central Peru: Tectonics, v. 7, p. 895928.

Sébrier, M., Mercier, J.L., Mégard, F., Laubacher, G., and Carey-Gailhardis, E., 1985, Quaternary normal and reverse faulting and the state of stress in the central Andes of south Peru: Tectonics, v. 4, p. 739780, doi:10.1029/TC004i007p00739.

Siddall, M., Chappell, J., and Potter, E.-K., 2006, Eustatic Sea Level During Past Interglacials, in The climate of past interglacials, Amsterdam, Elsevier, p. 75-92.

Song, T.-R.A., and Simons, M., 2003, Large Trench-Parallel Gravity Variations Predict Seismogenic Behavior in Subduction Zones: Science, v. 301, p. 630-633, doi:10.1126/science.1085557.

Spratt, R.M., and Lisiecki, L.E., 2016, A Late Pleistocene sea level stack: Climate of the Past, v. 12, p. 10791092, doi:https://doi.org/10.5194/cp-12-1079-2016.

Stone, J.O., 2000, Air pressure and cosmogenic isotope production: J. Geophys. Res., v. 105, p. 2375323759.

Swirad, Z.M., Rosser, N.J., Brain, M.J., Rood, D.H., Hurst, M.D., Wilcken, K.M., and Barlow, J., 2020, Cosmogenic exposure dating reveals limited long-term variability in erosion of a rocky coastline: Nature Communications, v. 11, p. 3804, doi:10.1038/s41467-020-17611-9.

Thompson, W.G., and Goldstein, S.L., 2006, A radiometric calibration of the SPECMAP timescale: Quaternary Science Reviews, v. 25, p. 3207-3215.

Thouret, J.C., Worner, G., Gunnell, Y., Singer, B., Zhang, X., and Souriot, T., 2007, Geochronologic and stratigraphic constraints on canyon incision and Miocene uplift of the Central Andes in Peru: Earth And Planetary Science Letters, v. 263, p. 151-166.

Trenhaile, A.S., 2002, Modeling the development of marine terraces on tectonically mobile rock coasts: Marine Geology, v. 185, p. 341. 
Trull, T.W., Brown, E.T., Marty, B., Raisbeck, G.M., and Yiou, F., 1995, Cosmogenic 10Be and 3He accumulation in Pleistocene beach terraces in Death Valley, California, U.S.A.: Implications for cosmic-ray exposure dating of young surfaces in hot climates: Chemical Geology, v. 119, p. 191.

Vega, M., and Marocco, R., 2004, La sedimentación oligo-miocénica en el antearco del sur del Perú: Estudio estratigráfico y sedimentológico de la Formación Camaná: Boletín de la Sociedad Geológica del Perú, Publicación Especial, v. 5, p. 125-141.

Victor, P., Sobiesiak, M., Glodny, J., Nielsen, S.N., and Oncken, O., 2011, Long-term persistence of subduction earthquake segment boundaries: Evidence from Mejillones Peninsula, northern Chile: Journal of Geophysical Research (Solid Earth), v. 116, p. 2402, doi:10.1029/2010JB007771.

Viveen, W., and Schlunegger, F., 2018, Prolonged extension and subsidence of the Peruvian forearc during the Cenozoic: Tectonophysics, v. 730, p. 48-62, doi:10.1016/j.tecto.2018.02.018.

Wells, R.E., Blakely, R.J., Sugiyama, Y., Scholl, D.W., and Dinterman, P.A., 2003, Basin-centered asperities in great subduction zone earthquakes: A link between slip, subsidence, and subduction erosion? art. no. 2507: Journal of Geophysical Research-Solid Earth, v. 108, p. 2507, doi:10.1029/2002JB002072.

Wipf, M., Zeilinger, G., Seward, D., and Schlunegger, F., 2008, Focused subaerial erosion during ridge subduction: impact on the geomorphology in south-central Peru: Terra Nova, v. 20, p. 1-10.

1060 Zeumann, S., and Hampel, A., 2015, Deformation of erosive and accretive forearcs during subduction of migrating and non-migrating aseismic ridges: Results from 3-D finite element models and application to the Central American, Peruvian, and Ryukyu margins: Tectonics, v. 34, p. 1769-1791, doi:10.1002/2015TC003867.

Zeuner, F.E., 1952, Pleistocene Shore-lines: Geologische Rundschau, v. 40, p. 39-50, doi:10.1007/BF01803207.

\section{Supplementary material}

Table S 1. Uplift rates ( $\mathrm{mm} / \mathrm{a}$ or $\mathrm{m} / \mathrm{ka}$ ) calculated from the shoreline angles listed in Table 5.

\begin{tabular}{|c|c|c|c|c|c|c|c|c|c|c|c|c|c|c|c|c|c|c|c|c|}
\hline Site & Age (ka) & & Chala & & $\begin{array}{l}\text { Aguada } \\
\text { de la } \\
\text { Zorra }\end{array}$ & & $\begin{array}{l}\text { Pescad } \\
\text { ores }\end{array}$ & & & & $\begin{array}{l}\text { P. de } \\
\text { Bombo } \\
\text { n/Moll } \\
\end{array}$ & & & $\begin{array}{l}\text { Ilo: } \\
\text { Pampa } \\
\text { de Palo }\end{array}$ & & te & & $\begin{array}{l}\text { Boca } \\
\text { del Rio }\end{array}$ & & Arica \\
\hline$x(\mathrm{~km})$ & & 525 & 524 & 475 & 467.5 & 425 & 402 & 375 & 325 & 275 & 240 & 225 & 175 & 130 & 125 & 100 & 75 & 50 & 25 & 0 \\
\hline$+/-$ & & 25 & 3 & 25 & 2 & 25 & 7 & 25 & 25 & 25 & 50 & 25 & 25 & 10 & 25 & 15 & 25 & 5 & 25 & 20 \\
\hline MIS 5a & 85 & 0.46 & 0.39 & & & & & & & & & & & & & & & & & \\
\hline MIS $5 \mathrm{c}$ & 100 & & & 0.48 & & 0.47 & & & & & & & & & & & & & & \\
\hline MIS $5 \mathrm{e}$ & 125 & 0.58 & 0.54 & 0.49 & 0.46 & 0.46 & & 0.30 & & 0.26 & 0.18 & & & 0.20 & & & & & & 0.17 \\
\hline MIS 7a & 190 & 0.53 & 0.51 & 0.43 & & & & & 0.23 & 0.24 & & & & & 0.16 & 0.17 & 0.18 & & & \\
\hline MIS 7e & 225 & 0.54 & 0.49 & 0.45 & 0.43 & 0.42 & & 0.30 & 0.25 & 0.25 & 0.27 & 0.24 & 0.18 & & 0.22 & 0.24 & 0.22 & 0.22 & 0.20 & 0.22 \\
\hline MIS 9a & 280 & 0.51 & & & & & & & & 0.25 & & 0.22 & 0.21 & 0.21 & & & & & & \\
\hline MIS 9c & 321 & 0.51 & 0.47 & 0.40 & 0.40 & & & & & 0.27 & 0.24 & 0.24 & & 0.25 & 0.26 & 0.22 & 0.23 & 0.23 & & 0.18 \\
\hline MIS 11 & 404 & 0.48 & 0.51 & 0.42 & 0.39 & & & 0.28 & & 0.28 & 0.26 & 0.26 & & & 0.22 & 0.25 & 0.23 & 0.21 & 0.19 & \\
\hline MIS 13 & 500 & & 0.47 & 0.37 & & 0.34 & & & & 0.27 & 0.27 & 0.27 & 0.23 & 0.24 & & 0.25 & 0.22 & 0.20 & 0.20 & 0.19 \\
\hline MIS 15 & 570 & & 0.47 & & & & 0.29 & 0.27 & 0.29 & 0.29 & 0.27 & 0.27 & 0.27 & & 0.26 & 0.26 & 0.24 & 0.24 & 0.22 & 0.22 \\
\hline MIS $17 \mathrm{c}$ & 700 & & 0.43 & & & 0.28 & 0.29 & 0.28 & & 0.27 & & 0.26 & & & 0.24 & 0.23 & & 0.25 & 0.22 & \\
\hline MIS 19 & 790 & & 0.44 & & & & 0.31 & & & & 0.28 & 0.25 & 0.24 & & 0.22 & & 0.22 & & 0.23 & \\
\hline $\begin{array}{c}\text { Average uplift rate } \\
(\mathrm{mm} / \mathrm{a})\end{array}$ & & 0.51 & 0.47 & 0.44 & 0.42 & 0.39 & 0.30 & 0.29 & 0.26 & 0.26 & 0.25 & 0.25 & 0.23 & 0.23 & 0.22 & 0.23 & 0.22 & 0.22 & 0.21 & 0.20 \\
\hline $\begin{array}{c}\text { estimated } \\
\text { uncertainty } \\
(\mathrm{mm} / \mathrm{yr})\end{array}$ & & 0.05 & 0.07 & 0.04 & 0.05 & 0.05 & 0.05 & 0.05 & 0.04 & 0.04 & 0.04 & 0.04 & 0.04 & 0.03 & 0.04 & 0.04 & 0.04 & 0.04 & 0.04 & 0.03 \\
\hline$\%$ & & $9.5 \%$ & $13.8 \%$ & $10.1 \%$ & $11.5 \%$ & $12.8 \%$ & $16.5 \%$ & $16.7 \%$ & $14.1 \%$ & $15.3 \%$ & $17.1 \%$ & $15.8 \%$ & $15.9 \%$ & $14.4 \%$ & $15.6 \%$ & $17.0 \%$ & $16.6 \%$ & $16.9 \%$ & $18.3 \%$ & $17.0 \%$ \\
\hline
\end{tabular}

